\title{
Critical Approaches to Security in Europe: A Networked Manifesto
}

\author{
C.A.S.E. COLLECTIVE*
}

\begin{abstract}
In the last decade, critical approaches have substantially reshaped the theoretical landscape of security studies in Europe. Yet, despite an impressive body of literature, there remains fundamental disagreement as to what counts as critical in this context. Scholars are still arguing in terms of 'schools', while there has been an increasing and sustained cross-fertilization among critical approaches. Finally, the boundaries between critical and traditional approaches to security remain blurred. The aim of this article is therefore to assess the evolution of critical views of approaches to security studies in Europe, discuss their theoretical premises, investigate their intellectual ramifications, and examine how they coalesce around different issues (such as a state of exception). The article then assesses the political implications of critical approaches. This is done mainly by analysing processes by which critical approaches to security percolate through a growing number of subjects (such as development, peace research, risk management). Finally, ethical and research implications are explored.
\end{abstract}

Keywords critical theory $\cdot$ security studies $\cdot$ collective intellectual • sociology of IR

\section{Introduction}

$\mathrm{T}$

IHIS MANIFESTO IS THE RESULT of collective work. The 'author' of this article, referred to as the c.a.s.e. collective, is a network of both junior and senior researchers who share an interest in critically examining contemporary practices of security. The aim of the article is to collectively assess the evolution of critical views of security studies in Europe, discuss their theoretical premises, examine how they coalesce around different issues, and investigate their present - and possibly future - intellectual ramifications. The specificity of this text thus lies in the very way it has been thought and written through a networked collective. ${ }^{1}$

1 The initiative was taken in Paris in June 2005, at a workshop entitled 'Critical Approaches to Security in Europe'. The initiative for gathering those who were interested in the changing landscape of security theory in Europe was strongly inspired by a piece by Ole Wæver (2004a) on this theme, entitled 'Aberystwyth, Paris, Copenhagen: New "Schools" in Security Theory and Their Origins Between Core 
The article is driven by two broad motivations. First, the authors share the view that, over the past two decades, important innovations in the study of 'security' have emerged among European scholars in particular (Wæver, 2004a). Although the genesis of these innovations involves scholars on both sides of the Atlantic, these approaches have arguably gained momentum and density in Europe, leading to the emergence of distinctive European research agenda(s) in the traditionally US-dominated field of 'security studies'. Consequently, it was felt that the time had come to evaluate these 'European' approaches, both in order to increase their exposure and to push them further in specific directions. Second, the aim of working and writing as a collective, a network of scholars who do not agree on everything yet share a common perspective, is based on a desire to break with the competitive dynamic of individualist research agendas and to establish a network that not only facilitates dialogue but is also able to speak with a collective voice. In this sense, the article can be read as a 'manifesto'. ${ }^{2}$

The article is organized as follows. It begins by reviewing the emergence of a heterogeneous corpus of critical literature within the field of security studies in the 1990s, along with the moves that led to its structuration in what has been called the 'Copenhagen', 'Aberystwyth' and 'Paris' schools (Wæver, 2004a). ${ }^{3}$ It argues, however, that this categorization can be misleading if taken too seriously. Indeed, rather than pinning down these schools geographically, the section shows how Aberystwyth, Copenhagen and Paris are dispersed locations associated with specific individuals and debates much more than unitary schools of thought. As such, the article will show how the dialogue between different scholars has shaped the conceptual discussion through a set of encounters, producing the appearance of 'schools' talking to each other.

This is followed by a more detailed discussion of the clusters of innovations associated with the three 'schools', outlining their main contributions, intel-

and Periphery'. The conference took place under the sponsorship of COST Action A24 on 'The Evolving Social Construction of Threats', and was organized in collaboration with the CHALLENGE programme, the CERI and the Centre d'Etudes Européennes at the Institut d'Etudes Politiques de Paris. For more information, see http:/ / critical.libertysecurity.org.

2 In order to understand the composition of the text, we believe it is important to briefly explain its genesis. After the COST Paris Training School, paper-givers and additional doctoral candidates gathered and elaborated a first draft of the current article. One, two or three members of the collective wrote each section of the article, regularly exchanging comments and suggestions. At various subsequent stages, drafts were read, commented upon and amended by Didier Bigo, Jef Huysmans, Michael Williams and Ole Wæver. The article then came back to the students, who were responsible for the final shape of the article. In addition, we would like to thank the three anonymous reviewers, as well as Felix Berenskoetter and Rob B. J. Walker, who have been instrumental in commenting upon and editing this manifesto.

${ }^{3}$ Wæver (2004a) lists 'hard-core postmodernists' and 'feminists' under 'other participants'. Because we begin from the suggestive classification that informs Wæver's analysis, this article necessarily works within, but also seeks to problematize, both geographical and theoretical limits. Although very interesting work drawing on Michel Foucault, Jacques Derrida or Jacques Rancière (such as that of Benjamin Muller, Peter Nyers, Patricia Molloy, Lene Hansen and Roxanne Doty) is not directly discussed, such work needs to be considered within a conversation that is now rapidly expanding. 
lectual context and cross-fertilization. By pointing to some of the theoretical insights, and dilemmas, that have emerged out of these 'schools', the section opens up for the main part of the article, which deals with new paths to explore for critical approaches to security in Europe.

The third section draws attention to how the analytical innovations outlined previously can be used to investigate issues such as the spread of the security label to other fields of research and practice, questions about exceptionalism, governmentality and risk, as well as the politics of belonging and the privatization of security. We also show how these new fields of enquiry provide new problematizations and add to the literature in terms of conceptual articulations and theoretical implications.

In the fourth section, we provide one possible answer to the persistent interrogations raised by constructivist/reflexive approaches, such as about how critique provides useful insights not only for analysis and critique, but also for active engagement in international politics. This question plugs into a wider debate over the status of producers of knowledge, the role of 'security' intellectuals, and modes of intervention in politics. What underpins critical approaches to security in Europe is the identification and denunciation of depoliticization, both in the social realm and in the realm of academia. The present article is therefore to be understood in part as a call for the return of a certain number of issues to the realm of politics. We contest a vision of research as detached from political contingency and action, as well as the scholastic illusion that tends to inform critical work, the critique of texts does not produce, per se, either political effects or resistance. This manifesto can therefore also be read as an argument against research without politics, which we believe can be tackled by a collective engagement and work.

\section{Critical Approaches to Security: A History of Encounters}

Theories in the social sciences do not occur in a vacuum. They are tied to and developed in relation to specific socio-historical (external) and intellectual (internal) contexts in which they emerge and/or to which they are applied. In terms of intellectual context, 'critical turns' in security studies have to be understood through the intellectual transformations occurring in social and political theory (see, for example, Ashley, 1984). CASE 4 was influenced by and part of a critical literature contesting a political and social science

${ }^{4}$ When broadly referring to the critical/reflexive literature on security, we will use the capital initials CASE (Critical Approaches to Security in Europe). 'CSS' refers to the precise 'Critical Security Studies' project, and 'c.a.s.e. collective' refers to the group of scholars who have contributed to this manifesto. 
that thought of itself as value-free and looked at its research object from an impartial Archimedean point. This critical literature emphasized the impact of socio-political processes on the emergence and structuration of political questions and institutions and the immanent presence of normative political choices in social science and political theory. In terms of socio-historical context, the emergence of the new social movements of the late 1970s and the 1980s, the formation of an internal security field in Europe, the second Cold War and Détente in the 1980s, and the end of the Cold War are among the key historical events that were important for the development of CASE.

However, to establish a direct causal link between the development of CASE and the internal and external contexts of its emergence without attending to the actual practices of and encounters between the actors of the field during that period would amount to an exaggeration of this relation, leading to an overly simplified narrative of what actually happened in the security studies field in the 1980s. As Ken Booth (1997: 98) reminds us, 'there is a tendency to assume that changed conceptions of the world are, for academics, either the result of being persuaded by a decisive book or being shocked by major events in world politics. People seem determined to make us either simply disciples or positivists'. Instead, personal encounters, material conditions or the very contingency of life itself also play an important role in the emergence of certain ideas and approaches. An examination of the trajectories of security scholars, their interactions, influences and transformations, would provide us with a more complex understanding of the configuration of the field.

CASE has developed through two series of encounters between what have been construed as schools of thought (Wæver, 2004a). The first encounters took place between scholars associated with the Aberystwyth and Copenhagen schools. Both schools have strong roots in political theory, as well as in IR debates and their repositioning in relation to peace research and strategic studies. The third group of academics, referred to as the Paris School, has its roots not in IR but in political theory and the sociology of migration and policing in Europe. The second series of encounters that were constitutive for CASE was between this third group of people and people associated with the Copenhagen and Aberystwyth schools of thought. These two sets of encounters have resulted in an increasingly institutionalized platform for discussing security issues.

However, it would be a mistake to reduce CASE to these three schools of thought. As a result of individual engagements and, probably more importantly, their institutionalization via European research projects and the founding of the International Political Sociology section and journal in the International Studies Association, CASE has expanded. Despite its strong European intellectual roots, in terms of people, CASE has included a number of researchers who are not usually directly associated with any of the three 
schools of thought. Most notable are Rob Walker's crucial ventures at the crossroads of political theory and security studies in IR through his writings and his editing of the journal Alternatives.

While we largely focus on the 'European' densification and singular structuration of critical perspectives on security studies, this point is an opportunity to stress the strong yet oft-overlooked connections between CASE and the 'dissident' modes of thought (Ashley \& Walker, 1991) that emerged in the mid-1980s through a set of encounters between mostly North American scholars. These encounters related to and produced an important corpus of literature, lying at the intersection between critical social theory (Ashley, 1987; Campbell \& George, 1990), political theory (Walker, 1980, 1987) and a variety of critical perspectives on the discipline of international relations, including contributions by Richard Ashley (1981, 1984), David Campbell (1998), Michael Dillon (1996), James Der Derian (1987), Jim George (1989, 1994), Bradley Klein (1990), Josef Lapid (1989) and Michael Shapiro (Der Derian \& Shapiro, 1989), among others. These 'dissident' perspectives engaged at the general level with the way in which Western social sciences were embedded in the specific political narrative of modernity, turning to international relations to stress its 'backwardness' (George, 1994) and its dependence upon the sovereign account of the possibilities and limits of political life (Walker, 1993). Beyond specific inputs on strategic and security studies (Klein, 1990; Walker, 1983, 1988; Chilton, 1985), and their contribution to a critical engagement with the modern concept of the political, the power/ knowledge nexus, the production of security discourses, the traditional disciplinarization of the academic field, and the political consequences of scholarly production, constitute a significant part of the conceptual background of CASE. We will come back to these aspects in the next section. But, first, we need to return to the encounters that informed the formation of a European configuration of critical outlooks on security.

In Europe, the existence of various perspectives on peace and security such as alternative defence and peace research during the Cold War, and the works of scholars such as Johan Galtung and Dieter Senghaas - makes it somewhat misleading to point to the 1980s as the historical phase during which an intellectual 'rupture' from orthodox approaches to security occurred. Giving more credit to this intellectual inheritance in the development of contemporary rethinking of security studies, Ken Booth (1997: 86-87) notes that while the end of Cold War, as a historical event, provoked an intellectual crisis for strategists adopting an orthodox approach to security, it was less disturbing for those who had already raised their concerns about the weaknesses of the dominant approaches to security in IR. This partly explains why peace research institutes were important loci of new approaches to security during the 1980s and the 1990s in IR (Wæver, 2004b).

From its establishment in 1985 to its closure in 2004, the Copenhagen Peace 
Research Institute (COPRI) has been one of the institutes wherein collective research on security that was theoretically informed yet empirically oriented was carried out in Europe. ${ }^{5}$ Rather than focusing on grand theoretical debates within IR, the research of COPRI emphasized the development of new concepts in order to understand security dynamics at work in Europe during that period (Huysmans, 1998b: 483-484). One of the most innovative works within CASE, the securitization theory, was developed through creative processes within COPRI. This approach defines security as a speech act. It argues that security issues are the political outcome of the illocutionary force of security agents and that one of the most effective ways of analysing security issues is through the discursive practices in different security sectors (Wæver, 1995: 54; Buzan, Wæver \& de Wilde, 1998).

In the critical security studies literature, what is generally referred to as 'Critical Security Studies' (CSS) is associated with scholars such as Keith Krause, Michael Williams, Ken Booth and Richard Wyn Jones. Owing much to the vision of critical theory in IR developed initially by Robert Cox, but also drawing on analytical inspirations such as the Frankfurt School and the post-positivist movement in IR theory, CSS sought to make explicit the largely statist and military-oriented assumptions of traditional security studies as a means of opening the field to greater theoretical scrutiny and debate, as well as allowing it to address a broader range of issues (Krause \& Williams, 1996, 1997). ${ }^{6} \mathrm{~A}$ further development of this critical project (sometimes called 'capital C' critical security studies) is what has come to be known as the 'Aberystwyth School'. In the view put forward by Wyn Jones and Booth, the axis of security studies should be the emancipation of individuals. Specifically, Booth and Wyn Jones's Frankfurt School-oriented critical approach suggests that realism's military-focused, state-centred and zerosum understanding of security should be replaced by a collaborative project that would have human emancipation as its central concern (Booth, 1991, 2005a; Wyn Jones, 1999, 2001; Sheehan, 2005). Today, this approach has developed to forge its own particular emancipatory 'theory of security' and research agenda (Booth, 2005b: 260).

Parallel to the development of these critical security studies agendas in IR, the political construction of security was also an important concern for a number of researchers analysing policing practices, the formation of an internal security field in Europe and the securitization of migration from a more political sociological and political theory perspective. These researchers

${ }^{5}$ COPRI hosted various researchers, such as Barry Buzan, Ole Wæver, Jaap de Wilde, Morten Kelstrup, Pierre Lemaitre, Egbert Jahn and Lene Hansen, whose research interests and scholarly directions cover a broad spectrum (see Guzzini \& Jung, 2004). A serious turn, however, came from the entry of Barry Buzan into COPRI in 1988 as director of one of the research projects of the institute: 'Non-Military Aspects of European Security'.

${ }^{6}$ Critical Security Studies, a volume edited by Krause \& Williams (1997) that includes contributions from various scholars associated with CASE, is considered the major text of this approach. 
introduced an agenda focusing on security professionals, the governmental rationality of security, and the political structuring effects of security technology and knowledge. With the exception of Huysmans, most were working in Paris with Didier Bigo and the journal Cultures et Conflits. Hence, Wæver's labelling of them as the 'Paris School' (Bigo, 1996; Bigo \& Guild, 2005; Huysmans, 2000, 2006; Tsoukala, 2004; Ceyhan \& Tsoukala, 1997; Bonelli, 2005; Hanon, 2000).

Whereas developments in Aberystwyth and Copenhagen took place largely within IR and through exchanges with the existing experts in the fields of international security, strategic studies and peace research, the works of the researchers associated with the Paris School had varied disciplinary locations, including political sociology, criminology, law and IR, and interacted with experts in areas broadly covered by internal security. What bound them together was a research interest in policing as a structuring practice, the politicization of societal insecurities (including hooligans, migration and border controls) and the structuration of internal security fields. Disciplinary boundaries between security analysis in IR, on one hand, and criminology and continental political sociology of security, on the other, made the prospect of a productive debate between Copenhagen and Aberystwyth, on the one hand, and Paris, on the other, unlikely. In addition, since much of the work that falls under the Paris School was initially carried out in French, a language barrier also needed to be broken down for the encounter to take place.

From the perspective of an IR and English-language readership, the sequence between the three schools was seen as Copenhagen, then Aberystwyth, with Paris as a late-comer. And this is still the presentation adopted by many contributions that add to the mainstream IR debate on security. This narrative usually starts with the contribution of Barry Buzan's People, States and Fear in 1983, and moves from there to the perspectives of Copenhagen and Aberystwyth, with the occasional addition from Paris as though it were an 'enlargement' of the concept of security - or even a dilution of the concept (Croft \& Terriff, 2000; David, 2000). Such a perspective involves a form of teleological vision in terms of progress or backlash between the schools. We will see later that the theoretical elements given by the three approaches of critical security studies are far from being an enlargement of a substantial security 'realm'. From a political sociology and criminology perspective, the sequence is different, especially in the French readership for whom Copenhagen arrived late. ${ }^{7}$

7 This story can be traced back to the 1970s, with the influence of so-called French theorists introducing 'constructivist' agendas in North America. Foucault, Barthes, Derrida, Deleuze (and to a lesser extent Bourdieu) were both lost in translation and discovered during the 1980s. They activated fierce debates in literature, political theory and post-colonial studies, reaching history, sociology, political science and finally IR in the mid-1980s. A transformed and reinvigorated (un)French theory developed by US and Canadian scholars then circulated back, helping partially to stop the attacks these theses were facing 'at home'. These readings, as well as the writings of various French expatriates, opened a sphere 
While the representation of schools of thought, then, helps to establish analytical categories as a first step for mapping the disciplinary field, a further investigation into these subdisciplinary identities reveals the fallacies of essentializing what otherwise are flexible groups of researchers. Wæver's (2004a) recent study also underlines the difficulty of drawing clear-cut dividing lines between the three schools. Despite its title, it was not so much about their differences than about a sociological explanation of their parallel emergence as a collective phenomenon. However, the naming of schools (neorealism, English School, Copenhagen School, etc.), usually by outsiders or critics, tends to strengthen their identities and produce debate in terms of monolithic schools. Yet, as Williams (1999: 343) has put it, 'both theoretical and political reality are rarely so conveniently structured, and to present them as such rarely advances our understanding of either'. To reconcile these two realities, our work would benefit from a sociological reading that takes into consideration the contingencies that structure academic debates. ${ }^{8}$

The many exchanges between the members of the different approaches succinctly described above have not led to a deepening of conceptual trenches, but to the realization that there is enough common ground between the researchers to facilitate constructive debate and to develop new conceptual tools and empirical research from the initial works. Cooperation across and through conceptual differences, which is a key activity within the c.a.s.e. collective, has recently been institutionalized in a number of major research networks. It is to this institutionalization, which makes it increasingly superfluous and misleading to talk about totally distinct - much less opposed or competing - schools in Aberystwyth, Copenhagen and Paris, that we now turn.

of discussion on otherness, migration, identity, borders, sovereignty and the place of the politics professional, as well as a reflexive approach to technology (Latour, Sfez). However, the new location of the debate in France was paradoxically in sociology (Bourdieu, Boltanski) and political science (Lacroix), including public policy (Lascoumes) and history (Noiriel), as well as criminology (Ericson, Haggerty, Garland, Sheptycki, Wacquant), but not in philosophy and political theory. Finally, political sociology and IR, which were always less separated, found common ground in this 'comeback' and explored it through the questions of migration, minorities and forms of political dissent (Bigo, 1992; Bigo \& Hermant, 1988; Lascoumes \& Moreau-Capdevielle, 1983).

${ }^{8}$ For CASE, converging interest on migration and security created the conditions for a few contingent encounters to take place. Wæver was invited to Paris in 1995, and Bigo had by then written critically about the Copenhagen School. Huysmans, who worked on both the concept of security in IR and the securitization of migration in the EU, met Bigo at the conference organized by the ECPR Standing Group on International Relations in Paris in 1995. Huysmans acquired a crucial role as the initial interlocutor of the 'Paris School' with critical security scholars and in defining the specificity of the Paris approach. In the 1990s, a mutually enriching dialogue between Huysmans and Bigo, on the one hand, and among Huysmans, Bigo and Wæver, on the other, led to a debate about societal security and the importance of blending practices and speech acts in order to strengthen the theory of securitization promoted by the Copenhagen School (Bigo, 1998; Huysmans, 1998b; Wæver, 1998; Balzacq, 2005). Also, the collaboration between Alternatives and Cultures $\mathcal{E}$ Conflits and the initiation of an International Political Sociology section played an important role in sustaining exchanges across the disciplinary and linguistic boundaries. 


\section{Late Institutionalization(s)}

Encounters among different scholars/schools, as discussed above, were characterized by informal and undirected exchanges and confrontations. By institutionalization(s) we mean a set of more formalized, long-term relations that allow us to talk about a common European research agenda on critical security issues. The use of the plural form 'institutionalization(s)' serves to remind us of the multiple paths of cooperation leading towards institutionalization: research networks, journals, panels and training of a future generation of critical scholars.

The aim of the c.a.s.e collective is precisely to go beyond the artificial boundaries in order to combine a variety of critical approaches under a common framework without, nonetheless, reducing one approach to another. Three research networks ${ }^{9}$ enabled research to focus on conceptual explorations of state, modern politics and exception; empirical investigations of a variety of actors, such as the police, the military, European bureaucracies and privatization of security; and topical engagement ranging from antiterrorism measures, migration and asylum policies to databases and surveillance. These research networks further sustained the inter-disciplinary opening towards researchers from sociology, anthropology, law and political theory. Second, critical security approaches shifted geographically. The Northern European states, the UK and France had developed a three-school debate, which now received fresh impulses from Eastern and Southern Europe. It is too early to assess the effects of this interdisciplinary and geographical widening, but it will most likely enrich conceptually and empirically critical approaches to security in the near future.

The institutionalization of critical approaches to security was assisted by the increasing density of interactions within major international gatherings, journals, edited books and the training of coming generations of scholars. These late institutionalization(s) naturally create significant challenges for CASE, as most of its participants have so far sustained a rather un-formal and un-attached dialogue with one another. The c.a.s.e. collective is developing and expanding a new forum for this dialogue. Related challenges pertain to the continuous efforts made to provide bridges among these approaches - for instance, how CASE can bridge the language barriers. With English being the

9 Three research networks - financed by the European Commission and primarily focused on European security - have been crucial for the institutionalization of CASE: ELISE ('European Liberty and Security'), which ran from 2002 to 2005, provided the initial impetus to a formal network of cooperation on critical security approaches across some European countries. It brought together seven institutional partners from six countries. This cooperation was enlarged under CHALLENGE ('The Changing Landscape of European Liberty and Security'), an integrated project running from 2004 to 2009 with 23 institutional partners. Finally, a complementary research network known as COST Action 24 ('The Evolving Social Construction of Threats'), running from 2004 to 2008, brought together 23 scholars from 13 European countries. These three research networks institutionally display personal affinities and intellectual convergences conducive to the progressive institutionalization of CASE. 
lingua franca of contemporary academia, how will the language barrier play out in the future? How can particular academic influences be brought to the fore of the English-speaking community? Then, a productive dialogue among CASE researchers and others in academia will depend on how effectively CASE can open up to the non-academic world. Finally, the production of dialogue across particular positions will also depend on whether CASE can speak to a non-European audience. Many of these questions will be touched upon within the frame of this manifesto; yet, before that takes place, it is important to note that beyond schools and encounters are specific theories and research programmes that cohered into these 'schools'. Theories and research programmes provided the ground upon which commonalities across each 'school' were identified, leading to, for instance, internal changes within each theory through the influence of another, attempts to face the key strengths of other theories providing impetus for extensions and elaborations, as well as parallel and joint exploration of new theoretical and empirical challenges. The next part of this manifesto will provide a synthetic overview of the theories and research programmes of each of the 'schools', as well as their points of juncture and fertilization.

\section{The Politics of Security}

\section{The Uses of Identity: Processes and Implications}

Ever since Bill McSweeney (1996) first coined the term 'Copenhagen School' to refer to their work, the theoretical contributions of Buzan, Wæver and others have combined three main conceptual ideas: securitization, sectors/referent objects and (regional) security complexes (Buzan, 1991, 2004; Buzan, Wæver \& de Wilde, 1998; Buzan \& Wæver, 2003; Wæver, 1989a, 1995, 2000, 2003). The reflections of the Copenhagen School are the result of a rare theoretical merger between something like an 'English School constructivist realist' coming from a strategic studies background (Buzan) and a self-proclaimed 'post-structural realist' strongly influenced by the works of Derrida and Kissinger (Wæver). This merger, and the diversity and heterogeneity in the thinking of each single author, creates a complex and dynamic, yet also vulnerable, theoretical position, drawing upon a broad range of diverse influences. Often as part of controversies and critiques, much attention in the past has been attributed to the idea of securitization and, in particular, securitizations using identity as a referent object (Buzan et al., 1993). Yet, the recent publication of a fully fledged theory of regional security complexes (Buzan \& Wæver, 2003) has made clear that single elements of the theory can perhaps best be understood in conjunction, by taking into account how 
processes of securitization in the theory work in combination with the concepts of sectors/referent objects and security complexes.

The idea of securitization describes processes in which the socially and politically successful "speech act" of labelling an issue a "security issue" removes it from the realm of normal day-to-day politics, casting it as an "existential threat" calling for and justifying extreme measures' (Williams, 1998: 435). These processes can have different 'referent objects', depending on whether they belong to an economic, environmental, political, military or societal sphere (what Buzan and Wæver call 'sectors'). The idea of sectors allows the authors to be more systematic with respect to their general claim that, in principle, anything can become securitized. Yet, only if a claim to treat something with exceptional measures is accepted by a relevant audience does a 'securitizing move' (the mere claim) turn into a (successful) securitization (exceptional measures are actually enabled). With regard to the societal security sector, Buzan and Wæver argue that the referent object is often identity. Looking at real-world security rhetorics, they claim, one will observe that an issue like migration has often been treated as an issue of security through reference to a threat to national or transnational identity (see, for example, Huysmans, 2000). More precisely, migration is often the case of an overlap in the security rhetoric of economic ('jobs') and societal security ('national identity') (Buzan, Wæver \& de Wilde, 1998; Sheehan, 2005). Moreover, since identity-related securitizations often appeal to the emotions of their audiences, certain layers of the security rhetoric may also be more tacit, invoking myths of stability and unity that can only be understood fully from within a community.

It was the combination of securitization with the societal sector and the referent object of identity that led to a major controversy towards the end of the 1990s (McSweeney, 1996, 1998; Buzan \& Wæver, 1997; Williams, 1998). McSweeney initiated the debate by arguing that Buzan and Wæver treat identity as a fixed entity. This would be theoretically inadequate, because identity would always be fluid and contingent, stemming from the discursive constructions of an only imagined community. What McSweeney had in mind was thinking of identity issues as processes of identification. Therefore, he stressed the always political and decision-based nature of identity issues. With that, McSweeney opened the securitization-identity nexus to a perspective that makes it possible to examine how a securitization impacts on processes of identification. Rather than treating identity as a referent object as, for example, in the case of Northern Ireland - a securitization can lead people to identify with things because of a particular securitization. In contrast, the Copenhagen School treats identity issues as more stable and sedimented (Buzan \& Wæver, 1997: 243; Buzan, Wæver \& de Wilde, 1998: 205) by focusing on how a fluid identity is (artificially) frozen by a securitizing move (Williams, 2003: 520). In this sense, the event/process of securitization is 
understood as an event/process of signification - that is, an event or process of fixing meaning by the securitizing act.

While the McSweeney debate was concerned with the micro-dynamics of securitization and identity, the fully fledged regional-security-complex theory of Regions and Powers (Buzan and Wæver, 2003) has introduced a broad macro perspective on world politics based on the idea of securitization. Here, the securitization of identity is just one dimension among many others that can constitute the pattern of amity and enmity in a region. Again, the precise pattern depends on the real-world securitizations of actors. Thus, threats and conflicts can be perceived as mainly being military-political, environmental, societal and/or economic (which resonates with the sectors approach developed in Security: A New Framework of Analysis).

To determine the distinct security dynamics of different regions in the world, Buzan and Wæver look at global, interregional, regional and domestic levels. The most important regional level is defined by the polarity structure of regional powers, which - in contrast to great powers - only impact on the security dynamics within a region, constituting the regional structure as unipolar, bipolar or multipolar. In terms of regional patterns of amity and enmity, Buzan and Wæver allow regions to range from conflict formation (e.g. South Asia) to the dense institutional and normative net of a security community (Europe), thereby empirically operationalizing Wendt's claim against Kenneth Waltz that 'cultures of anarchy' may range from Hobbesian to Kantian, depending on 'what actors make of it' (Wendt, 1992, 1999). In other words, the concept of security complexes is broader, incorporating not only security communities but also the more realist picture of 'conflict formations' present in many regions of the world. In their own terminology, a 'security community' is a situation in which there are no securitizations among the main actors of a region, a rare case of 'asecurity' in world politics (Wæver, 1998; Buzan \& Wæver, 2003: 343-376).

Merging the thinking of Buzan and Wæver creates a thought-provoking and innovative conglomerate of more static versus more dynamic, more objectivist versus more relativist, and more substantialist versus more relational elements (McSweeney, 1996: 82; Stritzel, 2006). The many intellectual influences and contrasting theoretical premises realize the old English School pledge for methodological and theoretical pluralism, but they make the ideas of Buzan and Wæver at the same time also vulnerable to diverging interpretations, as well as vigorous criticism, conceptual modification and theoretical extension (e.g. Balzacq, 2004, 2005; Stritzel, 2005, 2006).

\section{Unmaking Security: Desecuritization and Emancipation}

The securitization of identity has brought home the realization that discourses (and practices) have political effects. These effects range between the 
'tactical attractions' of securitization as attention-grabbing and the structuring of communities on the model of 'political realism' (Huysmans, 1998c; Williams, 2003). As 'a kind of mobilization of conflictual or threatening relations, often through emergency mobilization of the state' (Buzan, Wæver \& de Wilde, 1998: 8), securitization does more than just potentially open the political scene to groups from the extreme right, for example. It entails structural effects by reconfiguring and ordering societies on the model of emergency or exception (Aradau, 2004; Behnke, 2006; Huysmans, 2004b). Securitization (Copenhagen School) and emancipation (Aberystwyth School) are two concepts that attempt to grapple with these ambiguous effects.

As securitization is defined in opposition to normal politics, as a politics of exception or 'abnormal politicization' (Alker, 2005: 197), unmaking it implies a retrieval of the conditions of normal politics. Desecuritization would therefore bring issues back to the 'normal haggling of politics' (Buzan, Wæver \& de Wilde, 1998: 29). Although it has been suggested that the normal politics implied by the framework of securitization is that of liberal democracy (Aradau, 2004; Behnke, 1999; Huysmans, 2004b), normal politics remains undefined in the Copenhagen School framework. Attempts to theoretically unmake securitization, however, engage with a twofold understanding of normal politics: politics as normality (the objective socio-political order) and politics as normativity (the principles and ethical concepts that can transform the status quo). Although normative intent is implicit in any description of normality, desecuritization can be thought as politics of normality and emancipation as politics of normativity.

Desecuritization can be seen as an attempt at retrieving the normality of politics. Huysmans (1998c: 576) has defined desecuritization as 'unmak[ing] politics which identifies the community on the basis of the expectations of hostility'. The discursive construction of security frames normal politics as a political spectacle of alternative discourses. Through being located 'within the realm of political argument and discursive legitimation, security practices are thus susceptible to criticism and transformation' (Williams, 2003: 512). The discursive construction of security allows for its parallel discursive deconstruction, and normality appears as a contested process of construction/deconstruction. If desecuritization is anchored in the core of security analysis, the tension between discursive construction and the meaning of exceptional politics remains to be explored. Moreover, the role of discursive construction/deconstruction has already been subjected to intense criticism from more sociological approaches that draw attention to the 'authority' to speak.

Emancipation, in a formulation that has become defining for the Aberystwyth School, is a normative engagement with normal politics. Booth (1991: 319) has argued that emancipation should take precedence over concerns with power and order, as 'emancipation, not power or order, produces 
true security. Emancipation, theoretically, is security.' The normativity of the Aberystwyth School is defined as security, given that security is a 'powerful political concept . . . that energizes opinion and moves material power' (Booth, 2005c: 23) and that can be mobilized to emancipatory ends. Security is also distinguished from order and power and redefined as inclusive of individuals. All those who have been left out of the traditional remit of security need to become its subjects.

This understanding of security has steered their critical project towards the 'realities of security' that have been made invisible by 'the traditional mindset of those who have dominated or disciplined International Relations' (Booth, 2004: 8). Uncovering the realities of security (or rather insecurity) entails locating human rights abuses, the oppression of minorities, the powerlessness of the poor and violence against women (Booth, 2004: 7). Securitypower-normality is replaced by security-emancipation-normativity, with emancipation disentangling security from power and achieving a fuller and more inclusive realization of security.

However, the normative separation of security from power and order is problematic, as it accounts neither for the transformation of normality nor for the political effects of security. Other critical scholars who felt akin to the 'emancipation-oriented understanding of the theory and practice of security' (Wyn Jones, 2005: 215; see also Alker, 2005) have become aware of the need to reformulate the concept of emancipation in relation to normality and not simply normatively. Besides the debatable Habermasian idea of communicative rationality as embedded in normality and thus immanently transforming the order of the normal, engagement with the concept of emancipation in its relation to both normality and normativity has almost been entirely absent. ${ }^{10}$

What is at stake in the redefinition of emancipation is not simply the idea of retrieving normality or normatively constituting it, but that of defining what normality is. In a Foucault-inspired approach, normality is the result of the exclusions and forms of disciplinary and biopolitical regulation of populations (Dillon, 1995; Elbe, 2005; Huysmans, 2004a). Security is therefore not simply exceptional, but has constitutive effects upon the normal. Normality is simultaneously a field of struggle, where technologies for constituting subjects and ordering the social come up against the intransigence of political agency and the resistance of political subjects. Migrants and refugees, for example, engage in daily practices of resistance or bio-agency against securitization, which cannot be separated from the operations of power (Muller, 2004; Nyers, 2006). Although these practices can be seen as having an emancipatory effect, they are often insecuring for migrants and would therefore not fit in the equation emancipation=security, as Booth has proposed.

10 See, however, Aradau (2004) and Wyn Jones (2005). 
The Paris School has also redefined normality as constituted by professionals through technologies for ordering and managing social problems. The struggle would therefore shift from political agency to the institutional level of the professionals involved in the definition of threats and the technologies to govern them. Unmaking security would entail the disruption of the 'regime of truth' created by the professionals of security. Yet, neither definition of normality as struggle - on the side of the subjects constituted by practices of security or by those of security professionals - considers normativity and its relation to the normal ordering of the social. The most difficult challenge for theorizing emancipation would be to engage in careful consideration of what normality and normativity mean both for securitization and for the possibility of its unmaking.

\section{Mapping the Field of the (In)security Professionals}

For the Paris School, two convergent factors explain the reshaping of the concept of (in)security. Desecuritization, via reassuring discourses or different techniques of protection (e.g. video cameras), does not always reduce insecurity or increase confidence in the political. Security is not the opposite of insecurity. How security is defined conditions what is considered as insecurity (risk, threat). Policing insecurity is then a mode of governmentality, drawing the lines of fear and unease at both the individual and the collective level (Bigo, 2005; Huysmans, 2006). The second element, more difficult to tackle, is the emergence and consolidation of professional networks of security agencies that try to monopolize the truth about danger and unease through the power-knowledge nexus.

This conception of security points towards a different understanding of securitization as meaning the capacity to control borders, to manage threats, to define endangered identities and to delineate the spheres of orders. It thus shifts our attention in three ways. First, instead of analyzing security as an essential concept, contested as it were, the Paris School proposes treating security as a 'technique of government' (Foucault, 1994). Second, rather than investigating intentions behind the use of power, this approach concentrates on the effects of power games (Bigo \& Guild, 2003; Huysmans, 2000, 2002). Third, instead of focusing on 'speech acts', the Paris School emphasizes practices, audiences and contexts that enable and constrain the production of specific forms of governmentality (see Balzacq, 2005; Bigo, 2000; Bonditti, 2004, 2005: 131-154; Ceyhan, 1998). Consequently, this approach argues that, today, the field of security is determined not only by the sovereign power to kill but also by the discursive ability to produce an image of the enemy with which the audience identifies. All processes of securitization are connected to 'a field of security constituted by groups and institutions that authorize themselves and that are authorized to state what security is' (Bigo, 2000: 195; 
emphasis added). Thus, to attend to the study of securitization is to focus on the creation of networks of professionals of (in)security, the systems of meaning they generate and the productive power of their practices.

The Field as Methodology. Bourdieu's (1966: 865-906) concept of field informs most of the research of those who embrace a sociological approach to security. A field is a distinct social space consisting of interdependent and differentiated positions. In other words, a field is a 'network or a configuration of objective relations between positions' (Bourdieu, 1992: 72-73). To liken (in)securitization to the notion of field is, first, to invite scholars to explore the relations among security agencies, their status, roles, activities and institutional settings. The agents, we assume, are involved in field struggles. The analysis in terms of social spaces therefore requires an empirical investigation of the implications of these fights on the boundaries of the field and the extent to which they affect its existence.

Four main traits mark out the field of (in)security professionals (Bigo, 2006). First, the social space of the professionals of security functions as a 'field of force, or a magnetic field', the dynamic of which creates homogeneity of interests - not of identity. Understood in this way, a field fuses different and often competing perceptions and worldviews into a unified picture of what otherwise could not be captured by a single concept. Second, this social space is a field of struggles. Of course, actors need not share the same means nor pursue a similar end. Some agents are offensive, others defensive. Yet, once a field is constituted, it widens or shortens, contingent on the outcome of the power games that regulate the interactions among the players. It must be noted that players are not always conscious of the game they are playing (habitus). By the same token, fields may produce undesired effects. Third, and tied to the previous idea, the social space of the professionals of security is a field of domination. Although fields are distinct social spaces, their boundaries remain permeable. Indeed, and this is the fourth trait, the field of (in)security professionals is a transversal field, the trajectory of which reconfigures formerly autonomous social universes and shifts the borders of these former realms to include them totally or partially in the new field. The struggles that ensue demonstrate that these boundaries are never fixed once and for all (Bigo, 2005: 83-84). Thus, it is difficult, if not impossible, to understand the manner in which some discourses, however well founded, are cancelled out, if one does not examine how social spaces operate (Balzacq, 2004).

The Field as Practice: Internal and External Security. Fields only exist if they produce field effects. The inevitable question, then, is how exactly does this occur? On various occasions, Bigo (2000, 2001, 2005) has made a series of increasingly embroidered statements on the functional and geographical extensions of internal security. This conflation of internal and external security coincides, he notes, with the conversion of realist and neorealist narratives of security. Thus, realists and neorealists (Posen, 1993) are no 
longer reluctant to use concepts developed in international relations (such as the idea of the security dilemma) to account for what used to be restricted to the competence of domestic politics (e.g. ethnic conflicts). A major consequence of the broadening of internal security activities is the export of policing methods in world politics and, in return, the routinization of military operations in the national arena (Bigo, Guittet \& Smith, 2004: 5-34).

The merging of internal and external security offers distinctive views about field effects. For instance, some security agencies that received little attention in the past (e.g. gendarmerie, customs, border guards, immigration officers) are now at the centre of the security field, because their productive power seems to be best suited to alleviating contemporary challenges. In other words - and this is the crux of the argument - the field of the professionals of (in)security functions like a Möbius strip: the location of agents (inside/outside) is not fixed. Of the many factors suggested and examined by the Paris School, three are of significance, namely: the configuration of context, the nature of the issue at stake and, finally, the complexion of power struggles among (in)security professionals, within or beyond flexible boundaries of the security field (see Bigo, 2001; Balzacq, forthcoming). Most important, though, is that if different agencies belong to the same field of the professionals of (in)security, the inherent differences between kinds of threats disappear. This means that the restructuring of the field leads, logically, to the design of a semantic continuum of threats, ranging from irregular migration to terrorism. This continuum has real consequences not only for its intended targets, but also for security agencies and their relation to the political.

Drawing on Bourdieu, the Paris School has managed to circumscribe the problem raised by the Copenhagen School, whereby the emergence of speech acts was underspecified and their effects too broad, in comparison with other practices of power. However, the Paris School's strategy is not without problems. Focusing on struggles within a field cancels out an interest in those who could be called the 'professionals of nothing', those who 'at this minute, are being starved, oppressed, or shot' (Booth, 1997: 114). Consequently, practices of resistance are located within a field or among professionals of different fields (for example, judges versus security professionals), but leave out the multiple and complex ways in which 'the dangerous' themselves resist practices of security. Moreover, by focusing on practices at the expense of principles that hold together political communities, the Paris School does not leave room for the possibility of reappropriating terms (even problematic ones such as security) and redeploying them in different contexts. Many of the terms that define the discourses of professionals are not scientific concepts, but general terms like democracy, freedom or equality. In their universal address, these terms can be reappropriated and redeployed by those who would have had no access to the field and no adequate form of capital. 


\section{New Research Directions}

Having sketched out the interconnections and tensions between the plurality of critical approaches to security in Europe, we turn towards the actuality of the collective's research, as well as possible research paths for the future. For the purposes of this manifesto, we have focused on four directions that have emerged from our research: the implications of expanding security to other fields - or what we metaphorically have termed 'security traps'; the question of exceptionalism; risk analysis; and the 'politics of belonging'. These four lines of research engage with several of the impasses and tensions in critical studies, and propose different modalities of tackling 'security' critically.

\section{Tackling the Security Trap(s)}

Nowadays, matters of 'peace and security', as well as 'security and development', are considered closely related. These nexuses have been referred to as 'mergings'. ${ }^{11}$ Such mergings lie at the core of new research agendas in security studies. Indeed, by extending the field of security to new social fields, such as peace and development, they allow for new research agendas within security studies. However, before exploring the possibility of common research directions between critical peace research, development studies and CASE, we need to critically engage the notion of 'merging' that participates in the widening of the contemporary security agenda.

The question of the 'widening of the field of security' has given rise to fierce debates. The implicit argument of many of the 'wideners' is that by securitizing new issues such as peace and development, one encourages politicians to deal with them in a positive way. However, such an approach might be problematic. The widening of the security agenda, when justified by a concern to free people from fear and threat, might run into what we have called the 'security trap'. Talking about a 'security trap' refers both to the nonintentional dimension of the consequences of widening and to the fact that these consequences might conflict with the underlying intention. It refers to the fact that one cannot necessarily establish a feeling of security, understood as a feeling of freedom from threat, simply by securitizing more issues or by securitizing them more.

The process of securitization is a specific form of politicization that appeals to the professionals of security. It points not only to the fact that 'one has to deal with the problem', but also to how 'one has to deal with it in a coercive way'. As many critical scholars have warned, when transforming a societal issue into a security issue, one risks having the issue securitized for oneself by more established security professionals (Bigo, 1996; Wæver, 1995). In

\footnotetext{
11 See Guzzini \& Jung (2004) for peace research, and Duffield (2001) for development.
} 
other words, even when widening the security agenda with the explicit intention of 'demilitarizing' international security, the signifier 'security' might on the contrary subordinate these issues to governmental security agencies, thus foreclosing the range of political options available to deal with the issues. Even if securitization is a political process, it might legitimate practices that depoliticize the approach to the securitized issues (Buzan, Wæver \& de Wilde, 1998; Olsson, 2006a,b) by giving preference to coercive approaches. This can be seen as a first aspect of the security trap.

The precise mechanisms through which the process of securitization might lead to the involvement of coercive state agencies have, however, to be further analysed. Drawing on the work of French historian Jean Delumeau (1986), Bigo has shown that the securitization of societal issues raises the issue of protection by insecuritizing the audience the security discourses are addressing. This insecuritization will translate into a social demand for the intervention of coercive state agencies through reassurance discourses and protection techniques. In other words, the processes of securitization and of insecuritization are inseparable. This leads him to speak of the process of (in)securitization (Bigo, 1995). This means that one is confronted with a security dilemma: the more one tries to securitize social phenomena in order to ensure 'security', the more one creates (intentionally or non-intentionally) a feeling of insecurity. This happens, for example, when the military is called in to patrol streets in order to prevent terrorist attacks. Even if the underlying idea is to reassure the population, it might also create a feeling of panic (Guittet, 2006). As a logical consequence, the politics of maximal security are also politics of maximal anxiety. This is the second aspect of the security trap.

The irony is that even the most careful and critical scholar aiming at avoiding the first and second traps might unwillingly participate in the securitization of new issues when analysing how these issues are de facto framed in terms of security. When analysing the securitization of a phenomenon, how can one avoid playing into the hands of the 'deep structures' of the security discourse and thus participating in its discursive securitization? This question of the 'normative dilemma of security studies' is the third aspect of the security trap. Highlighting the non-intentional and adverse effects of analysing the widening of security, it remains the most difficult to handle (Huysmans, 1998a).

Exposing these three aspects of the security trap is especially important in the context in which security has increasingly colonized various other fields.

\section{Peace and Security}

According to Wæver (2004b), 'peace' and 'security' are closely related concepts, but at times - especially during the Cold War - their connotations have differed dramatically. 'Security' has been the catchword for the Western 
establishment, and 'peace' has been used by its political and academic critics. In the 1980s, the relationship between the power-focused strategic studies and peace research became less hostile, and the disciplines found some shared ground in the concept of security (see Buzan, 1984). Since then, the fields have merged to a large extent to become security studies (Guzzini \& Jung, 2004): peace and security have become 'two sides of the same coin'.

Originally, peace research was a critical voice in academic debates. Peace research has been based on the idea that the world is manmade and thus changeable (Wallensteen, 1988; Dunn, 1991). This view is one of the common characteristics of peace research and CASE. Another shared idea is the wider understanding of security. As early as the 1960s, peace researchers began to expand the concept of violence to include structural forms of violence. Violence was understood as everything that prevents people from realizing their potential. Johan Galtung called this absence of structural violence 'positive peace' (Galtung, 1969: 183). When peace researchers began to speak about security, they redefined it in terms previously used for violence and peace, leading to some of the 'most extreme widenings in the history of security thinking' (Wæver, 2004b: 62).

Despite some attempts to recreate peace research that is informed by critical theories (e.g. Alker, 1988; Patomäki, 2001), mainstream peace research has become narrowly empirical. It does not reflect on its ontological foundations, epistemological premises, or the origins and implications of its concepts (Rytövuori-Apunen, 1990: 289). ${ }^{12}$ CASE has taken over the critical role in the field of 'peace and security'. Peace researchers could learn from CASE in building deeper understandings of peace research's central concepts and in adopting new forms of criticism and reflexivity. This is especially important now, when military interventions are more often carried out in the name of peace than in the name of security (Wæver, 2004b: 62). Peace researchers should also reflect on the normative dilemmas of writing, speaking and practising peace.

In academic practice, critical peace research would thus be very close to CASE, but it could move beyond it with a more participatory understanding of the role of researchers. Traditionally, the role of security scholars has been that of advisers to the Prince or critics of the establishment (see below). Both of these roles have been assigned to peace researchers, but there have also been calls for more practical participation in conflict resolution. In their role as mediators, researchers can help the parties to a conflict in building collective emancipatory projects ${ }^{13}$ and at the same time learn from this activity (see Väyrynen, 2005).

\footnotetext{
12 Rytövuori-Apunen's claim holds to a large extent to articles published in the main peace research journals during 1992-2002; see Jutila, Pehkonen \& Väyrynen (forthcoming).

${ }^{13}$ For example, a territorial dispute between Ecuador and Peru was resolved through the creation of a binational natural park proposed by Galtung; see Galtung (2004: 79-81).
} 


\section{Security and Development}

The post-Cold War security-development nexus (Duffield, 2001) has been developed in the UN, other major international institutions (such as the World Bank), influential NGOs (such as the Carnegie Commission), the European Union and major policy documents of states (e.g. the USA's National Security Strategy of 2002). The merging of development and security is understood to represent a normative and progressive transformation in the means and aims of security, from a narrow and instrumental focus on national, state security, towards the protection of human life globally.

The merging of security and development is most clearly represented by the concept of human security, introduced by the United Nations Development Programme's (1994) Human Development Report. A number of other discourses have emerged that are both part of the human security discourse and analysed separately: for example, 'new wars' (Kaldor, 2001), 'greed and grievance' (Berdal \& Malone, 2000), and 'failed state' models of conflict and social unrest.

The political implications of the merging of security and development are profound. In these discourses, non-Western war, or social unrest or conflict, has been emptied of political, social and historical content - both external, in terms of the international context within which conflict occurs, and internal. Conflict is understood as a private, predatory activity, fostered by elites pursuing degenerate, criminal projects. Human rights violations that are committed are understood as being committed for their own sake, rather then as a consequence of war. Social instability is understood as arising out of biological needs rather then political struggle. Individuals in weak or unstable societies appear as pre-political, driven by their biological needs into conflict with one another. These populations are seen as vulnerable individuals who are in a permanent situation of being 'at risk' from the effects of chronic threats such as hunger and disease. This focus on the vulnerability of individuals and the merging of development and security acts to pathologize the activity of entire populations in weak or unstable states. The problems associated with underdevelopment are no longer understood as amenable to political or even economic solutions, but to be resolved on the terrain of security practices.

During the initial period of decolonization, the capacity or internal makeup of a state did not threaten its formal international political equality (Duffield \& Waddell, 2004: 18). The relinking of security and development reverses this and formally reintroduces hierarchy back into international relations through differentiation between the 'dangerous' underdeveloped states and the developed states. Within the Western democracies, the transformation of security from a necessarily limited political relationship between a territorially bound state and its citizens to a global moral principle 
also has serious implications. Intervention in and regulation of underdeveloped states becomes emptied of political content and transformed into an ethical necessity.

The contribution of this section to the manifesto of the c.a.s.e. collective is to suggest the need for a critical approach to the merging of security and development. This needs to begin by challenging the depoliticized analysis of the supposed threats from underdevelopment (McCormack, forthcoming), discourses such as that of the 'new wars', and the 'ethical' nature of postCold War Western intervention (Chandler, 2003) and regulation of underdeveloped and impoverished states.

\section{The Privatization of Security}

The trend of privatizing security, as reflected in the growing role of private security companies (PSCs) and private military companies (PMCs), offers a promising research agenda for CASE. This trend is indirectly linked to the contemporary widening of the field of security, and has been fuelled by the incapacity of public security agencies to reassure and to protect in the face of a broadening of the 'environment of threats'.

The issue of privatization is important for CASE, as it allows highlighting the fact that the contemporary field of security is transversal not only to the inside/outside distinction, but also to the public/private distinction (Bigo, 2003; Olsson, 2003; Abrahamsen \& Williams, 2006). The aim, here, is to understand what happens when discourses of (in)security, historically considered as enactments of state sovereignty, are said to refer to the presumably 'marketized' and 'democratized' (Thompson, 1994) realm of private security operators.

Anna Leander $(2005,2006)$ has analysed the political risks entailed by the 'commodification of violence' by showing that the supply side (PMCs) and the demand side (security demand) are inseparable: 'supply creates its own demand' through the discursive process of securitization. By highlighting the structural power the privatizing trend gives to private companies, she implicitly confirms the second aspect of the security trap: the maximal security option might validate itself a posteriori by fostering a feeling of insecurity. Hence, just as with peace and development, this new research agenda raises the question of the security trap and would benefit from sustained engagement with its three aspects.

\section{Security and Exceptionalism}

The question of exceptionalism has recently become a site of intense political contestation over the legitimacy or illegitimacy of recent transformations in security practices, especially in the context of the 'war on terror'. On the one 
hand, policymakers and their supporters have frequently argued that the rules of the game have changed, that this is a new kind of war, and that exceptional times require exceptional measures. The category of the exceptional has been invoked to justify and mobilize an array of violent and illiberal practices, including detention without trial, derogation from human rights law, complicity in torture, 'extraordinary rendition', the curtailment of civil liberties and the securitization of migration. On the other hand, critical approaches to security have converged upon the concept of exceptionalism as a means of analysing and contesting these transformations.

A key point of departure is Schmitt's ([1922] 1985: 5) declaration that 'sovereign is he who decides on the exception'. This sharply expresses the exceptional prerogatives claimed by political authorities (however conceived) in the name of security. For the Schmitt of Political Theology, 'the exception' is a situation of radical danger and contingency for which no prior law, procedure or anticipated response is adequate. It is a perilous moment that exceeds the limits of precedent, knowledge, legislation and predictability. Schmitt demonstrates the potent performative logic of security imperatives when he uses the vertigo induced by this awesome contingency to claim that 'the exception' brings about a fundamental existential necessity for unlimited, unconstrained, exceptional sovereign decision. For Schmitt, 'exceptionalism' is not simply an adjunct to 'normal' politics, but a more authentic expression of political authority that has the capacity to constitute new political and legal orders. ${ }^{14}$

The critique of Schmitt is simultaneously a critique both of deployments of Schmittian logic in security discourses and of the statist preoccupations of security studies. From this perspective, it is vital to note that 'the exception' and exceptionalism are not the same thing. The Schmittian strategy is to argue that the necessity of unlimited, unconstrained, exceptional sovereign power is brought about by the exceptional situation itself. The slipperiness of this move is exposed when it becomes clear that Schmitt's sovereign must also declare that the exception exists in the first place. Contra Schmitt, therefore, the 'necessity' of sovereign exceptionalism does not begin with 'objec-

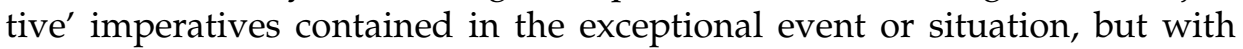
sovereign exceptionalism itself. Although exceptionalism legitimated on the grounds of 'objective necessity' can be performatively successful, its claimed positivistic basis rests on a hollow circular logic. Exceptionalism is from the outset fiendishly entangled in an authoritarian, decisionist politics that

14 Recent years have seen a raft of new English translations of Schmitt's work, including Legality and Legitimacy (Schmitt, [1932] 2004) and The Nomos of the Earth (Schmitt, [1950] 2003), and a corresponding expansion of Schmitt scholarship that extends the analysis of exceptionalism beyond its initial statist framings. Nevertheless, the more established Political Theology (Schmitt, [1922] 1985) and The Concept of the Political (Schmitt, [1932] 1996) remain key reference points for critical approaches to security because of the existential imperatives they sharply express. 
declares exceptional conditions (such as a state of emergency) in order to give legitimate authority to contentious policies and practices.

Whereas policymakers may claim that exceptional times require exceptional measures and thus invoke necessities supposedly brought about by exceptional danger, critical approaches question this logic. Necessity is a political claim, not an existential condition. An event or situation does not dictate a particular (exceptional) response, such as the curtailment of civil liberties or the erosion of constitutional checks and balances; the authorization of exceptionalism resides elsewhere. This prompts a series of critical questions: How do exceptions and exceptional situations come to be considered as exceptional? How are practices of exceptionalism and claims about exceptions authorized? Through what institutional, social, communicative and political processes? And what are the political implications?

What follows are just a few examples of the ways in which these questions have been pursued. Securitization theory (Wæver, 1995) offers resources for understanding how policymakers declare a condition of exceptional threat in order to legitimize practices of exceptionalism.

In contrast, Bigo (2002) argues that by focusing on elite discourses of danger and emergency, securitization theory reinforces a conception of the security field that is driven by the views and discursive strategies of elites. By focusing instead on the security professionals who manage 'unease' within society on a daily basis, exceptional security practices can be understood in the context of ongoing processes of technocratic, bureaucratic and market-driven routinization and normalization.

Williams argues that because claims about exceptions occur in the discursive field, they are open to 'a process of argument, the provision of reasons, presentation of evidence, and commitment to convincing others of the validity of one's position'. They therefore remain open to the emancipatory possibility of a communicative ethics that may 'avoid the excesses of a decisionist account of securitization' (Williams, 2003: 522).

These critical approaches respond to the challenge of Schmittian exceptionalism. They contest both claims to any kind of 'objective' exception or security situation and the Schmittian understanding of a monolithic sovereign authority. Instead, they analyse the social processes through which exceptionality is named, constructed, authorized and made to have very real political and violent effects. They offer vital resources for contesting the jump from the invocation of exceptional conditions to the legitimation of a politics of exceptionalism.

Yet, if we are to extend the critical project, then these approaches must be questioned in terms of their critical reach and ambition. Although securitization theory successfully contests the construction of insecurity and exceptionality, it risks the reification of dramatic elite exceptionalist discourses. Although the Paris School shifts focus from the dramatic to the routine, its 
'mapping' project tends towards a positivism that risks excluding more radical critical openings. And, finally, as pointed out above, emancipatory approaches still face difficult questions about the ambiguities of 'unmaking' processes of securitization.

Although critiques of Schmittian exceptionalism may abound, Walker (forthcoming) argues that 'the spirit of Carl Schmitt's exceptionalism has by no means been eradicated from contemporary political life', and not only in relation to the limits of the sovereign state but also in relation to the limits of the modern international system. Beyond the critique of Schmitt's overdetermined decisionist prerogatives and discourses of emergency reside more profound philosophical questions about the nature of limits and contingency. ${ }^{15}$

The critical challenge of the exception far exceeds the statist, securitized, Schmittian version: 'There comes a point where questions about limits, about origins, boundaries, and exceptions come back into sharp focus' (Walker, forthcoming). For example, is it possible to imagine an ethic or politics that does not ultimately suffer the problem of antagonistic or aporetic limits? The problem of the exception, once liberated from its Schmittian overdetermination, must come back to haunt the critical project at its ever-receding horizons.

\section{Security, Risk and Risk Management}

The concept of risk has recently permeated security studies. Arising from different philosophical traditions, different approaches to risk determine different perspectives in risk management, hinting at competing understandings of 'politics/the political' and 'security'. The objective here is to briefly describe two major approaches to risk in relation to security and to explore the potential of risk management in opening up some of the debates within the field.

Under a rationalist tradition, the concept of risk has evolved as a basis for decisionmaking under conditions of uncertainty (Daston, 1995; Hacking,

${ }^{15}$ CASE seems to share a belief in the possibility of eradicating exceptionalism. Yet, different interpretations of Schmitt regard the exception as the transcendent foundation of any order. For Prozorov (2005: 100), the problem of the exception is defined as that of the 'singular relation between order and the transgression that engenders it', between structure and event, between situations and their disruptions. The 'exception', however, is not simply 'an act' in Žižek's (2004) terms or an event that is simultaneously disavowed by an existing order and necessary for its functioning. The more interesting questions about the exceptions are raised by authors who have not received much attention yet within international relations: Alain Badiou or Etienne Balibar. Badiou's (1988) theory of the event can differentiate between 'progressive' and 'reactionary' events, between what we can still call desecuritization and the conservative revolutionary legitimation of order à la Schmitt. Balibar's (2002) discussion of the historical ambiguities of the 'subjectivity' of the sovereign can also open up modes of challenging practices of security at the horizon of sovereignty. Rather than solely bringing back the sovereign exception as the political and depoliticizing moment of governmentality, it is equally important to expose the processes through which governmental practices have achieved the effacement of the moment of decision and contingency. 
1990; Bernstein, 1998). Risk analysis works as an instrument in decisionmaking by evaluating future actions in terms of risk. As Luhmann (1993: 13) has argued, risk is conceptualized as 'a controlled extension of rational action'. Risk analysis is an estimation of future threats - an estimation that builds on the premise that risks can be classified, quantified and to some extent predicted, and that rational behaviour can help to manage or maybe even eliminate risk (Adams, 1995; Bernstein, 1998; Ewald, 1991; Power, 2004).

The modern tradition of risk, however, is being contested by Beck's theory of risk society. According to Beck, late modernity is characterized by society's inability to insure itself against risks that, on the one hand, exceed the calculable and, on the other, have catastrophic effects that cannot be compensated. Thus, according to Beck, the 9/11 terrorist events escaped rational predictions and have displayed the limits of modern insurance technology (Beck, 2002 , 2003). Within IR, this has given birth to a research agenda on 'reflexive security' that focuses on the management of the new and constructed risks that transcend national borders (Rasmussen, 2002, 2004). In the risk society thesis, hazards and insecurities are viewed as inevitable structural threats that can only be solved through cosmopolitanism, a world based on the negotiation of certain norms (Beck, 2005a,b; Boyne, 2001).

An alternative approach addresses risk as an instrument of governance rather than an organizing principle of life. Within this approach, which draws on the work of Michel Foucault, risk is recognized as a means for ordering reality - as 'a way of representing events in a certain form so they might be made governable in particular ways, with particular technologies and for particular goals' (Dean, 1999: 177). This approach has inspired analyses of risk in a variety of disciplines such as international relations, criminology, insurance and surveillance studies (e.g. Ewald, 1986; Ericson \& Haggerty, 1997; Garland, 2001; Lyon, 2003; Ericson, Doyle \& Barry, 2003). Two strategies have been described within the approach. Baker \& Simon (2002: 4) describe 'risk spreading' as the 'wide variety of efforts to conceive and address social problems in terms of risk', such as financial risk management, social security, police and national defence services, and environmental policies, among others. 'Risk embracing' is described, on the other hand, as the strategy that shifts the risk responsibility from the institutions to the individuals and corporations. It aims at constituting subjects that are made responsible through their management of risk (Baker, 2002). Practices of security can be understood as combinations of these two strategies. Risk is therefore a technology for the provision of security that transcends borders (Baker, 2000; Dillon, 2005; Petersen, 2006; Lobo-Guerrero, 2006); it involves different technologies and allows us to understand the multiplicity of form through which 'security' is governed nowadays.

Based on these perspectives, a challenge for critical security scholarship is to engender a debate between risk-based and threat-based interpretations of 
(in)security that will widen the traditional critical security agenda concerned with the mutual constitution of threats and identity (e.g. Krause, 1998; Campbell, 1998; Hansen, 2006). The claim of securitization theory that the political character of security is highlighted by the constitutive role of political identity and authority in the articulation of security threats offers an opportunity for this debate. Addressing security as risk management opens up the logic of security (Huysmans, 1998b) and moves from the concern over identity, territory, exclusion, neutralization and elimination of others, placing the analysis on a more explicit temporal dimension.

Risk management locates security in a direct relation to time, owing to its reckoning of futures. Of course, security statements have always had a temporal element insofar as they call for defence against future threats. Yet, the concept of risk seems better suited to exploring modulations of temporalities by shifting the focus from utterances referring to dangerous futures to the technologies and strategies by means of which the future is produced as computable, calculable and manageable. This debate has already begun through the analysis of insurance, particularly terrorism insurance, where risk, however incalculable, can still be mobilized as a security enabler while regulating moralities (Aradau \& Van Munster, 2005; Bougen, 2003; LoboGuerrero, 2006). Applications can be found in the area of security and development (Duffield, 2006; Lobo-Guerrero, 2005) and the management of civil contingencies such as environmental hazards, food security and health issues (see Dillon, 2005).

A second emergent challenge is that of exceptionalism, which is often present in routinized politics of unease (e.g. Agamben, 1998, 2005; Van Munster, 2004). As the discussion of security and exceptionalism has already indicated, the critical problem of 'the exception' is that of radical contingency. As pointed out repeatedly in Foucauldian approaches to criminology, insurance and welfare, risk management works to 'tame' contingency and order both temporal and special relations (O'Malley, 1998, 2000, 2004; Ericson, 1994; Garland, 2001). Beyond the 'worst-case scenario' rendition of 'the exception', risk management appears to work with an imaginary of calculability that is always already surpassed by the contingency of reality. An emerging question, therefore, is what happens with the state of exception and conceptualizations of security when practices of risk management are considered? This tension between exceptionalism and routinization within security studies should be taken seriously and should promote a critical research agenda dealing with the relationship or coexistence of risk and exceptionalism in all its different possible configurations (Aradau \& Van Munster, forthcoming). 


\section{The Politics of Belonging ${ }^{16}$}

The question of the nexus between identity and security, perhaps still a locus of conceptual tension between the different approaches, seems to leave open research paths in many directions. As a substantive noun, 'identity' already contains a reified understanding of what is at stake in what could be broadly framed as the 'politics of belonging'. Two main processes seem to be at stake when 'identity' is discussed: first, different processes of objectivation (identity cards, passports, bureaucratic categories) and subjectivation (individual or group alternative identifications) aimed at delimiting the group to be 'secured'; second, the mobilization of repertoires of enunciation and action that contain plans and routines for discourses and practices of security, as well as the 'right' way to play them out. A serious study of both these cultural practices and their ethical and moral referents, both structured and structuring through the agents' habitus is still a work in progress (see Guillaume, 2002). This would engage the 'statonational' obsession of IR literature, where 'national identities' are conceived as objectifiable elements of territorially bound societies. Moreover, it should provide an occasion to test the tools developed by critical approaches to security outside the 'Western' world and to abandon euro- and amerocentric agendas of (in)security.

Possible new directions could be explored along two complementary lines: first, along the line of time and historicity - through, for example, the question of memory; second, along the line of the heterogeneity of the spaces of practices of identity. If the question of the 'national identity' is to be explored more deeply, engaging the very large literature on 'nationalism', other spaces should also be explored: at the transnational level, the reticular social spaces of diasporas and transnational social movements in their relation to practices of security; at a supranational level, the practices of security entailed in the politics of identity of the European Union could be re-engaged.

\section{Collective Memory}

A first space for critical exploration of security in the vein of the politics of belonging is provided by the nexus between security and collective historical memory. Questions of collective historical memory lurk behind a plethora of security debates, ranging from the legitimacy of political violence to postconflict reconstruction and transitional justice (Bell, forthcoming; Müller, 2002). Collective memory plays a pivotal role in the constitution of collective discourses and practices of identification, as well as the formation and repro-

${ }^{16}$ We borrow this expression from John Crowley and scholars working on this question. Although we do not engage this literature in the present manifesto, we hope to be able to do so in the future (Favell \& Geddes, 1999). 
duction of the collective self and its respective other(s), which in turn shape constructions of security and insecurity and subsequent political action.

Unfolding the dynamics of collective memory's incorporation into the formulation of collective identity could thus shed light on the role of the politics of memory and historical trauma, and the heritage of founding violence in the constitution of security imaginaries and security policies of different collectivities. The study of the memory-security relationship could also help the c.a.s.e. collective to build further bridges with critical history. Just as the latter recognizes the dense ambiguity of the past and the infinitely negotiable character of collective memory, the impulse of critical approaches to security has been - and continues to be - opening up the notion and practices of 'security' in all of the latter's complexity and equivocality, thus complicating the neat picture of the security world that traditional security/ strategic studies tend to offer.

\section{Nationalism, Citizenship, Diasporas, Transnational Social Movements}

Different critical approaches have strongly emphasized the nexus between practices of security and practices of identity. As a referent object of securitization processes, 'societal security' has been the object of several discussions (Bigo, 1998; McSweeney, 1999: 109; Wæver, 1993, 1998; Buzan, Wæver \& de Wilde, 1998). Others have insisted on the role of bureaucratic categorization practices in the formation of (rejected) identities (Bigo, 1998) - or, more broadly, processes of othering (Campbell, 1998; Neumann, 1995, 1999). Even if this has already been done on important occasions (Wæver, 1993), it seems that the large literature on 'nationalism' (particularly after 1993) has to be explored and discussed (e.g. Gellner, 1983; Hobsbawm, 1990; Brubaker, 1996; Calhoun, 1997). Only recent works have started to explore this direction (Roe, 2004; Jutila, 2006).

Similarly, regarding the question of citizenship, the CASE tools would allow for seeing citizenship not only as defining the conditions under which one can be recognized as a full member of a community but also as a way of fixing the (secure) borders one should not cross when participating in a particular self-understanding/representation for fear of being perceived as, and thus becoming, another. The French veil affair (l'affaire $d u$ voile), for instance, provides strong evidence for the relevance of citizenship for expanding CASE to other fields of research (see Gianni \& Guillaume, 2004; Guillaume, forthcoming).

Less state-centred spaces of identity practices are still open venues for future research: if 'diasporas' are largely taken into account in their role as 'immigrants', critical approaches to security only in preliminary form engage the practices of security of diasporas as 'transnational communities' (Portes, 1998, 2001) or as 'emigrants' and their relation to state practices (Dufoix, 2000; 
Ragazzi, 2005). Similarly, the practices of transnational social movements are still left out of the picture.

\section{Revisiting the European Identity}

The CASE framework also offers significant potential for investigating developments connected with the European Union. A CASE-inspired research agenda, for instance, would involve reconceptualizing the mechanisms of Europeanization as transformative processes for political identities, where identities are not givens and the nature and outcome of the processes at stake are not taken for granted. The aim would be to reflect on how identities are re-produced through social practices, and how these practices are transformed, categorized and labelled as European. Implicitly, then, Europeanization is approached through an interrogation of processes of politicization and depoliticization (Davidshofer, 2006). This would imply studying, for example, how the definition of items of Community external relations/foreign policy entails competition among the various actors within these 'fields' (Buchet de Neuilly, 2005), which would not only involve positions on the contents of the actions considered, but also imply debates about how the Union should be acting on the international stage - and thus alternative conceptions of its political identity/identities. For example, an analysis could be developed of how practices defining the political identity of 'others' (e.g. 'candidate countries' for the enlargement process, 'neighbours' for the European neighbourhood policy [Jeandesboz, 2005], 'developing countries' in the context of the EU's aid and development policy) are structured around a certain claim to knowledge and constitute a form of power and an assertion of domination in the relations between the EU and third countries - similar, in fact, to the mechanisms of Orientalism exposed by Edward Said (1979).

\section{The Collective Intellectual: Being Relevant}

More clearly than many other fields of study in international relations, security studies has always been tied to security policymaking. At the end of World War II, for example, security analysts helped to construct a language by which the new nuclear reality could be grasped (Lawrence, 1996). More recent examples, such as the discourse on human security, show how knowledge about security can emerge as a co-production between theorists, analysts and policymakers. Even though scholarly practices are not identical to policy practices, it would be mistaken to regard security studies and security policymaking as clearly separated spheres. Consequently, we engage in this section 
with the broader relevance of the production of critical knowledge, as well as the constitution of the 'collective intellectual'.

Scientific communities engage with many exoteric communities, such as citizens, policymakers, journalists and other analysts, for at least three purposes: to gain justification for their work; to gather resources necessary for conducting research; and to influence political agendas. This triad of purposes needs to be kept in mind when speaking about relevance. ${ }^{17}$ Moreover, as the sociology of the sciences ever since the pioneering work of Ludwik Fleck ([1935] 1979) points out, the dialogue between scientific communities and their exoteric communities is never a one-way transfer from science to relevant actors, but an interactive pattern.

CASE scholars share a consensus that there is no clear boundary between the practices of theorizing security and practising security. An explicit outcome of recent debates has been agreement that any security analysis, theory, concept or publication has a political nature and hence potential policy effects, examined in studies of securitization. ${ }^{18}$

Social science communities are never relevant or irrelevant as such: the issue of relevance always involves the questions of relevance for and with whom. Relevance is a matter of 'becoming' relevant, not a static concept of 'being' relevant. If CASE wants to face the challenge of becoming relevant beyond plain justification strategies, variation in the types of knowledge and actors involved needs close attention.

\section{From Being Relevant to Becoming Relevant}

Thus, we need to ask what kind of knowledge does CASE attempt and claim to produce, and for what and whom might this be useful? While different strands of critical security studies have not generated a unanimous set of context-independent theoretical generalizations, challenging a dominant and constraining view of reality is nevertheless a trait common to all streams of CASE. The objective of creating emancipatory knowledge via the development of alternative truths has been, in particular, a central concern for some forms of critical security studies. The Aberystwyth School has especially tried to show how the concept of state security does not necessarily encompass security for the people. The Copenhagen School, on the other hand, has shown how invoking the concept of security is a discursive process that erases all rules of normal politics. This alternative insight puts a special kind of responsibility on people doing security, since invoking the word starts a process beyond democratic politics (Buzan, Wæver \& de Wilde, 1998: 211).

${ }_{17}$ We will leave the justification and resource-gathering problematiques to sociologists of security studies.

18 See 'the Eriksson debate' (Eriksson, 1999a,b; Wæver, 1999; Williams, 1999; Goldmann, 1999; Behnke, 2000, as well as Huysmans (2002). See also the section 'Critical Approaches to Security: A History of Encounters (above), which outlines the European specificity of CASE. 
Generating concrete technical knowledge has not been a primary focus for CASE scholars. Concrete analysis of practices and technologies, however, is a needed addendum to CASE, as it carries a promise of being able to provide relatively concrete knowledge to specialists on technologies of security.

The most direct contribution of CASE lies in its attempts to assist security practitioners in becoming more reflexive about their practices, as well as in helping them to cope with multiple truths, theories and technical knowledge. The Copenhagen School has explicitly sought to help security policymakers not by identifying threats but by putting 'an ethical question at the feet of analysts, decision-makers and political activists alike: why do you call this a security issue? What are the implications of doing this - or not doing it?' (Wæver, 1999: 334).

Like IR theory in general, a key debate within CASE has revolved around the purpose and 'usability' of theory. Critical or not, security scholars are generally caught in the dilemma of trying to inform aspects of policymaking while attempting to generate and study academically original questions. The price of sole focus on the latter is growing specialization and the closure of specific expertise into a continuously narrowing niche. This specialization runs contrary to 'commonsensical' policymakers, who usually prefer the concrete policy advice offered by think tanks.

The relationship between the study of security and the quest for security cannot be reduced to a simple research-to-policy one-way street. As Malin \& Latham (2001) have shown empirically, it is the interplay of security scholars' different practices - that is, research, practical innovation and participation in public debate - that matters. The traditionally conceived neat science-policy nexus is further complicated by the growing significance of new actors in the social scientific knowledge market, such as think tanks, consultancies, NGOs, social movements and the media. More controversially perhaps, some critical security scholars have called for eschewing 'the temptations of seeking the ears of soldiers and statesmen' altogether and instead focusing on the development of counter-hegemonic positions linked to emancipatory social movements (Wyn Jones, 1999: 6). Change usually comes about through the interplay between anti-establishment/radical/extra-parliamentarian challengers that move the boundaries of the possible and the rearticulation of 'reasonable' analysis and praxis by those who in the most general sense are part of the elite (see Wæver, 1989b).

\section{Dilemmas of Theory and Practice}

Being and becoming relevant induce a set of thorny dilemmas for CASE, namely, (1) autonomy versus relevance for the community; (2) the limits of steering the consequences of CASE-produced knowledge; and (3) the dilemma of impact upon political processes. 
First, becoming relevant includes deliberations with exoteric communities, but to what extent will these deliberations in turn influence academic practices? Autonomy is to a certain extent a necessary precondition for conducting solid academic research, and deliberations with clients may undermine this autonomy.

Second, if scholars lack the capacity to steer the use of their knowledge, how can they take responsibility for that knowledge? To take it to the extreme, should one also be responsible for 'that majority of the readings and usages that are misunderstandings?' (Wæver, 1999: 336). Given the impossibility of directly steering interpretation and usage, a careful balancing is necessary between relevance and responsibility.

Third, the analyst faces the dilemma of entering a political process that might entail negative consequences. What options are available to the security analyst when securitization is set in motion? Buzan, Wæver \& de Wilde (1998: 34-35, 204-206) argue that three options are open to the analyst who wishes to avoid sustaining or deepening the securitization process: (1) the analyst can stop speaking about the threat and hope that this will work as a desecuritizing process, avoiding the adoption of the agenda of the securitizing actor; (2) the analyst can divert attention to another threat; and (3) the analyst can contribute to a different interpretation of the threat being securitized through the analysis.

Finally, CASE faces the 'truth dilemma': is anyone interested at all in analyses that do not claim to speak the 'truth'? Do policymakers even care to listen when CASE is not speaking in the name of truth? Given that much of the public authority of science relies precisely on the idea of science speaking in the name of truth, how can scholars cope with a situation where they cannot claim to speak the 'truth' but are forced to do so by their exoteric communities?

CASE scholars cannot avoid these dilemmas, and certainly there are no easy solutions to them. If the practices that are pursued to tackle these dilemmas are indeed consequential for academic and policy discourses, CASE needs to openly debate these issues and to decide which practices it considers legitimate and appropriate. These dilemmas and the inherent complexity of specialist academic discourse do not make communication of research any easier. Yet, it is here that things can be improved most visibly. If CASE is to become more relevant in the future, the types of publications and audience to which it wishes to reach out may need to be broadened. As some have argued, 'it is from the popular literature that the statement obtains certainty, simplicity and vividness', and, indeed, 'the word becomes flesh' (Fleck, [1935] 1979: 117). 


\section{Against Research Without Politics}

To take this discussion one step further, we need to ask ourselves, as researchers and as a collective, what the claim of being 'critical' and representing a 'collective intellectual' entails for our engagement with the political. This question naturally can be extended to all CASE scholars. First, what do we mean by 'critical'? Are not all theories by definition critical (of other theories)? In virtue of which principle, as a networked collective, would we allow ourselves to be self-labelled as critical? What is so critical about the general perspective we are collectively trying to defend here?

From the Kantian perspective to the post-Marxist Adornian emancipatory ideal, from Hockheimer's project to the Foucaldian stance toward regimes of truth, being critical has meant to adopt a particular stance towards taken-forgranted assumptions and unquestioned categorizations of social reality. Many of these critical lines of thought have directly or indirectly inspired this critical approach to security in Europe project. Being critical means adhering to a rigorous form of sceptical questioning, rather than being suspicious or distrustful in the vernacular sense of those terms. But, it is also to recognize oneself as being partially framed by those regimes of truth, concepts, theories and ways of thinking that enable the critique. To be critical is thus also to be reflexive, developing abilities to locate the self in a broader heterogeneous context through abstraction and thinking. A reflexive perspective must offer tools for gauging how political orders are constituted.

This effort to break away from naturalized correspondences between things and words, between processes framed as problems and ready-made solutions, permits us to bring back social and political issues to the realm of the political. Being critical therefore means, among other things, to disrupt depoliticizing practices and discourses of security in the name of exceptionality, urgency or bureaucratic expertise, and bring them back to political discussions and struggles.

This goal can partly be achieved through a continuous confrontation of our theoretical considerations with the social practices they account for in two directions: constantly remodelling theoretical considerations on the basis of research and critical practice, and creating the possibilities for the use of our research in political debate and action. This raises questions about the willingness and modalities of personal engagement. While critical theories can find concrete expressions in multiple fields of practice, their role is particularly important in the field of security. Since engaging security issues necessarily implies a normative dilemma of speaking security (Huysmans, 1998a), being critical appears as a necessary moment in the research. The goal of a critical intellectual is not only to observe, but also to actively open spaces of discussion and political action, as well as to provide the analytical tools, concepts and categories for possible alternative discourses and practices. 
However, there are no clear guidelines for the critical researcher and no assessment of the impact of scholarship on practice - or vice versa. Critical approaches to security have remained relatively silent about the role and the place of the researcher in the political process, too often confining their position to a series of general statements about the impossibility of objectivist science. ${ }^{19}$

The networked c.a.s.e. collective and the manifesto in which it found a first actualization may be a first step toward a more precisely defined modality of political commitment while working as a researcher. Writing collectively means assembling different types of knowledge and different forms of thinking. It means articulating different horizons of the unknown. It is looking at this limit at which one cannot necessarily believe in institutionalized forms of knowledge any longer, nor in the regimes of truth that are too often taken for granted. It is in this sense that being critical is a question of limits and necessities, and writing collectively can therefore help to critically define a modality for a more appropriate engagement with politics.

* The c.a.s.e collective is Claudia Aradau, Thierry Balzacq, Tugba Basaran, Didier Bigo, Philippe Bonditti, Christian Büger, Stephan Davidshofer, Xavier Guillaume, EmmanuelPierre Guittet, Jef Huysmans, Julien Jeandesboz, Matti Jutila, Luis Lobo-Guerrero, Tara McCormack, Maria Mälksoo, Andrew Neal, Christian Olsson, Karen Lund Petersen, Francesco Ragazzi, Yelda Şahin Akilli, Holger Stritzel, Rens Van Munster, Trine Villumsen, Ole Wæver and Michael C. Williams.

\section{References}

Abrahamsen, Rita \& Michael C. Williams, 2006. 'Privatisation, Globalisation and the Politics of Protection in South Africa', in Jef Huysmans, Andrew Dobson \& Raia Prokhovnik, eds, The Politics of Protection: Sites of Insecurity and Political Agency. London: Routledge (34-47).

Adams, John, 1995. Risk. London: University College London Press.

Agamben, Giorgio, 1998. Homo Sacer: Sovereign Power and Bare Life. Stanford, CA: Stanford University Press.

Agamben, Giorgio, 2005. State of Exception. Chicago, IL: University of Chicago Press.

Alker, Hayward R., Jr., 1988. 'Emancipatory Empiricism: Toward the Renewal of Empirical Peace Research', in Peter Wallensteen, ed., Peace Research: Achievements and Challenges. London: Westview (219-241).

Alker, Hayward, 2005. 'Emancipation in the Critical Security Studies Project', in Ken Booth, ed., Critical Security Studies and World Politics. London: Lynne Rienner (189-214).

Aradau, Claudia, 2004. 'Security and the Democratic Scene: Desecuritization and Emancipation', Journal of International Relations and Development 7(3): 388-413.

19 Here, Foucault's (1995: 109) 'specific intellectual' working within specific sectors or the 'collective intellectual' ('raison d'agir') initiated around Pierre Bourdieu can provide us with examples of an articulation between scholarship and commitment. These historical examples of commitment, of course, should be discussed and could provide possible starting points for forms of collective commitment to come. 
Aradau, Claudia \& Rens Van Munster, 2005. ‘Governing Terrorism and the (Non-)Politics of Risk', Political Science Publications 11/2005. Odense: University of Southern Denmark.

Aradau, Claudia \& Rens van Munster, forthcoming. 'Governing Terrorism Through Risk: Taking Precautions, (Un)Knowing the Future', European Journal of International Relations.

Ashley, Richard K., 1981. 'Political Realism and Human Interest', International Studies Quarterly 25(2): 204-236.

Ashley, Richard K., 1984. 'The Poverty of Neo Realism', International Organization 38(2): 225-286.

Ashley, Richard K., 1987. 'The Geopolitics of Geopolitical Space: Towards a Critical Social Theory of International Politics', Alternatives 12: 403-434.

Ashley Richard K. \& Rob B. J. Walker, 1991. 'Reading Dissidence/Writing the Discipline: Crisis and the Question of Sovereignty in International Studies', International Studies Quarterly 34(3): 367-416.

Badiou, Alain, 1988. L'Être et l'événement [Being and Event]. Paris: Editions du Seuil.

Baker, Tom, 2000. 'Insuring Morality', Economy and Society 29(4): 559-577.

Baker, Tom, 2002. 'Risk, Insurance, and the Social Construction of Responsibility', in Tom Baker \& Jonathan Simon, eds, Embracing Risk: The Changing Culture of Insurance and Responsibility. Chicago, IL: University of Chicago Press (33-51).

Baker, Tom \& Jonathan Simon, 2002. 'Embracing Risk', in Tom Baker \& Jonathan Simon, eds, Embracing Risk: The Changing Culture of Insurance and Responsibility. Chicago, IL: University of Chicago Press (1-26).

Balibar, Étienne, 2002. 'Le Hobbes de Schmitt, le Schmitt de Hobbes. Préface' [Schmitt's Hobbes, Hobbes's Schmitt: Preface], in Le Léviathan dans la doctrine de l'Etat de Thomas Hobbes [The Leviathan in Thomas Hobbes's Doctrine of the State], ed. Carl Schmitt. Paris: Editions du Seuil (7-65).

Balzacq, Thierry, 2004. 'The Pragmatic Act of Security: Politics and Methods', unpublished manuscript.

Balzacq, Thierry, 2005. 'The Three Faces of Securitisation: Political Agency, Audience and Context', European Journal of International Relations 11(2): 171-201.

Balzacq, Thierry, forthcoming. Security and Indirect Effects: How Securitization Transforms International Politics, unpublished book manuscript.

Beck, Ulrich, 2002. 'The Terrorist Threat: World Risk Society Revisited', Theory, Culture \& Society 19(4): 39-55.

Beck, Ulrich, 2003. 'The Silence of Words: On Terror and War', Security Dialogue 34(3): 255-267.

Beck, Ulrich, 2005a. Power in a Global Age. London: Polity.

Beck, Ulrich, 2005b. 'War Is Peace: On Post-National War', Security Dialogue 36(1): 5-26.

Behnke, Andreas, 1999. 'Postmodernising Security', paper presented at the ECPR Joint Sessions, Mannheim, 26-31 March.

Behnke, Andreas, 2000. 'Inscriptions of Imperial Order: NATO's Mediterranean Initiative', International Journal of Peace Studies 5 (1); available at http://www.gmu.edu/ academic/ijps/vol5_1/behnke.htm (accessed 18 September, 2006).

Behnke, Andreas, 2006. 'No Way Out: Desecuritisation, Emancipation, and the Eternal Return of the Political - A Reply to Aradau', Journal of International Relations and Development (9)1: 62-69.

Bell, Duncan, ed., forthcoming. Memory, Trauma, and World Politics: Reflections on the Relationship Between Past and Present. Basingstoke: Palgrave Macmillan.

Berdal, Mats \& David Malone, eds, 2000. Greed and Grievance: Economic Agendas in Civil Wars. London: Lynne Rienner. 
Bernstein, Peter, 1998. Against the Gods: The Remarkable Story of Risk. New York: John Wiley \& Sons.

Bigo, Didier, ed., 1992. L'Europe des polices et de la sécurité intérieure [Polices and Internal Security in Europe]. Brussels: Editions Complexes.

Bigo, Didier, 1995. 'Grands débats dans un petit monde. Les débats en relations internationales et leur lien avec le monde de la sécurité' [Great Debates in a Little World: Debates in International Relations and Their Link with the World of Security], Cultures $\mathcal{E}$ Conflits 19-20: 7-48.

Bigo, Didier, 1996. Polices en réseaux. L'expérience européenne [Police in Networks: The European Experience]. Paris: Presses de Sciences Po.

Bigo, Didier, 1998. 'L'Europe de la sécurité intérieure, Penser autrement la sécurité' [Europe of Internal Security, Thinking Security Differently], in Anne-Marie Le Gloannec, ed., Entre Union et Nation. L'Etat en Europe [Between Union and Nation, the State in Europe]. Paris: Presses de Sciences Po (55-90).

Bigo, Didier, 2000. 'When Two Become One: Internal and External Securitisations in Europe', in Morten Kelstrup \& Michael C. Williams, eds, International Relations Theory and the Politics of European Integration, Power, Security and Community. London: Routledge (171-205).

Bigo, Didier, 2001. 'The Möbius Ribbon of Internal and External Security', in Mathias Albert, David Jacobson \& Yosef Lapid, eds, Identity, Borders, Orders: Rethinking International Relations Theory. Minneapolis, MN: University of Minnesota Press (91-116).

Bigo, Didier, 2002. 'Security and Immigration: Toward a Critique of the Governmentality of Unease', Alternatives 27(1): 63-92.

Bigo, Didier, 2003. 'Editorial - Les entreprises de coercition para-privées: de nouveaux mercenaires ?' [Introduction: Para-private Coercion Companies: The New Mercenaries ?] Cultures \& Conflits 52(4): 5-10.

Bigo, Didier, 2005. 'La mondialisation de l'(in)sécurité. Réflexion sur le champ des professionnels de la gestion des inquiétudes et analytique de la transnationalisation des processus d'(in)sécurisation' [The Globalization of (In)Security ? Reflections on the Field of the Professionals of Unease Management and Analysis of the Transnationalization of the (In)Securitization Process], Cultures $\mathcal{E}$ Conflits 58: 53-100.

Bigo, Didier, 2006. 'Globalized (in)Security: The Field and the Ban-opticon', in Didier Bigo \& Anastassia Tsoukala, eds, Illiberal Practices in Liberal Regimes. Paris: L'Harmattan (5-49).

Bigo, Didier \& Elspeth Guild, 2003. 'La mise à l'écart des étrangers. La logique du visa Schengen' [The Exclusion of Foreigners: The Logic of the Schengen Visa], Cultures $\mathcal{E}$ Conflits 49: 38-70.

Bigo, Didier \& Elspeth Guild, eds, 2005. Controlling Frontiers: Free Movement Into and Within Europe. Aldershot: Ashgate.

Bigo, Didier \& Daniel Hermant, 1988. La relation terroriste, analyse de la violence politique des organisations clandestines dans les democraties occidentals [The Terrorist Relation, Analysis of Clandestine Organizations' Political Violence in Western Democracies]. Paris : Etudes Polémologiques, Documentation Francaise.

Bigo, Didier; Emmanuel-Pierre Guittet \& Andy Smith, 2004. 'La participation des militaires à la sécurité intérieure: RU, Irlande du Nord' [The Participation of the Armed Forces in Internal Security: United Kingdom, Northern Ireland], Cultures \& Conflits 56: $11-34$.

Bonditti, Philippe, 2004. 'From Territorial Space to Networks: A Foucaldian Approach to the Implementation of Biometry', Alternatives 29(4): 465-482.

Bonditti, Philippe, 2005. 'Biometrie et maîtrise des flux. Vers une géo-technopolis du 
vivant-en-mobilité' [Biometry and Flows Mastering: Toward a Geo-Technopolis of Mobile Lives], Cultures $\mathcal{E}$ Conflits 58: 131-154.

Bonelli, Laurent, 2005. 'Un ennemi anonyme et sans visage' [An Invisible, Faceless Enemy], Cultures \& Conflits 58: 101-130.

Booth, Ken, 1991. 'Security and Emancipation', Review of International Relations 17(4): 313-326.

Booth, Ken, 1997. 'Security and Self: Reflections of a Fallen Realist', in Keith Krause \& Michael C. Williams, eds, Critical Security Studies: Concepts and Cases. London: UCL Press (83-120).

Booth, Ken, 2004. 'Realities of Security: Editor's Introduction', International Relations 18(1): 5-8.

Booth, Ken, ed., 2005a. Critical Security Studies and World Politics. London: Lynne Rienner.

Booth, Ken, 2005b. 'Beyond Critical Security Studies', in Ken Booth, ed., Critical Security Studies and World Politics. London: Lynne Rienner (259-278).

Booth, Ken, 2005c. 'Security', in Ken Booth, ed., Critical Security Studies and World Politics. London: Lynne Rienner (21-25).

Bougen, Philip, 2003. 'Catastrophe Risk', Economy and Society 32(2): 253-274.

Bourdieu, Pierre, 1966. 'Champ intellectuel et projet créateur' [Intellectual Field and Creative Project], Les temps modernes 246: 865-906.

Bourdieu, Pierre, 1992. Réponses [Replies]. Paris: Seuil.

Boyne, Roy, 2001. 'Cosmopolis and Risk: A Conversation with Ulrich Beck', Theory, Culture \& Society 18(4): 47-63.

Brubaker, Rogers, 1996. Nationalism Reframed: Nationhood and the National Question in the New Europe. Cambridge \& New York: Cambridge University Press.

Buchet de Neuilly, Yves, 2005. L'Europe de la politique étrangère [Europe's Foreign Policy]. Paris: Economica.

Buzan, Barry, 1984. 'Peace, Power, and Security: Contending Concepts in the Study of International Relations', Journal of Peace Research 21(2): 109-125.

Buzan, Barry, 1991. People, States and Fear: An Agenda for International Security Studies in the Post Cold War Era, 2nd edn (original edition 1983). London: Harvester Wheatsheaf.

Buzan, Barry, 2004. The United States and the Great Powers. London: Polity.

Buzan, Barry \& Ole Wæver, 1997. 'Slippery? Contradictory? Sociologically Untenable? The Copenhagen School Replies', Review of International Studies 23(2): 241-250.

Buzan, Barry \& Ole Wæver, 2003. Regions and Powers: The Structure of International Security. Cambridge: Cambridge University Press.

Buzan, Barry; Ole Wæver \& Jaap de Wilde, 1998. Security: A New Framework for Analysis. Boulder, CO: Lynne Rienner.

Buzan, Barry; Morten Kelstrup, Pierre Lemaître \& Ole Wæver, eds, 1993. Identity, Migration and the New Security Agenda in Europe. New York: St Martin's.

Calhoun, Craig J., 1997. Nationalism. Minneapolis, MN: University of Minnesota Press.

Campbell, David, 1998. Writing Security: United States Foreign Policy and the Politics of Identity, rev. edn (original edition 1992). Manchester: Manchester University Press.

Campbell, David \& Jim George, 1990. 'Patterns of Dissent and the Celebration of Difference: Critical Social Theory and International Relations', International Studies Quarterly 34(3): 269-293.

Ceyhan, Ayse, 1998. 'Analyser la sécurité: Dillon, Wæver, Williams et les autres' [Analysing Security: Dillon, Weaver, Williams and the Others], Cultures $\mathcal{E}$ Conflits 31-32: 39-63.

Ceyhan, Ayse \& Anastassia Tsoukala, eds, 1997. 'Contrôles: Frontières-Identités. Les enjeux autour de l'immigration et de l'asile' [The Control of Immigration: Myths and Reality], Cultures \& Conflits 26-27: 7-14. 
Chandler, David, 2003. 'Rhetoric Without Responsibility: The Attraction of "Ethical" Foreign Policy', British Journal of Politics E International Relations 5(3): 295-316.

Chilton, Paul, ed., 1985. Language and the Nuclear Arms Debate: Nukespeak Today. London: Pinter.

Croft, Stuart \& Terry Terriff, 2000. Critical Reflections on Security and Change. London \& Portland, OR: Frank Cass.

Daston, Lorraine J., 1995. Classical Probability in the Enlightenment. Princeton, NJ: Princeton University Press.

David, Charles Philippe, 2000. La guerre et la paix: approches contemporaines de la sécurité et de la stratégie [War and Peace: Contemporary Approaches to Security and Strategy]. Paris: Presses de Sciences Po.

Davidshofer, Stephan, 2006. 'La gestion de crise et l'Union européenne: modalités d'une réappropriation' [Crisis Management and the European Union: Modalities of a Reappropriation], in Vincent Chetail, Cedric Van Der Poel, Sylvie Ramel \& René Schwok, eds, Prévention, gestion et sortie des conflits [Prevention, Management Of and Exit From Conflict]. Geneva: Institut Européen de l'Université de Geneva (1-26).

Dean, Mitchell, 1999. Governmentality: Power and Rule in Modern Society. London: Sage.

Delumeau, Jean, 1986. Rassurer et protéger: le sentiment de sécurité dans l'Occident d'autrefois [To Reassure and Protect: The Feeling of Security in the West of Former Days]. Paris: Fayard.

Der Derian, James, 1987. On Diplomacy: A Genealogy of Western Estrangement. Oxford: Basil Blackwell.

Der Derian, James \& Michael Shapiro, eds, 1989. International/Intertextual Relations: Postmodern Readings of World Politics. Lexington, MA: Lexington.

Dillon, Michael, 1995. 'Sovereignty and Governmentality: From the Problematics of the New World Order to the Ethical Problematic of the World Order', Alternatives 20: 323-368.

Dillon, Michael, 1996. Politics of Security: Towards a Political Philosophy of Continental Thought. London: Routledge.

Dillon, Michael, 2005. 'Global Security in the 21st Century: Circulation, Complexity and Contingency', Chatham House ISP/NSC Briefing Paper 05/02: 2-3. London: Chatham House.

Duffield, Mark, 2001. Global Governance and the New Wars: The Merging of Development and Security. London: Zed.

Duffield, Mark, 2006. 'Racism, Migration and Development: The Foundations of Planetary Order', Progress in Development Studies 6(1): 68-79.

Duffield, Mark \& Nicholas Waddell, 2004. Human Security and Global Danger: Exploring a Governmental Assemblage. Lancaster: Department of Politics and International Relations, University of Lancaster.

Dufoix, Stéphane, 2000. 'La structuration de l'expérience collective à l'étranger' [The Structuration of Collective Experience Abroad], CEMOTI 30: 319-332.

Dunn, David J., 1991. 'Peace Research Versus Strategic Studies', in Ken Booth, ed., New Thinking About Strategy and International Security. London: Harper Collins Academic (56-72).

Elbe, Stefan, 2005. 'AIDS, Security, Biopolitics', International Relations 19: 403-419.

Ericson, Richard V., 1994. 'The Division of Expert Knowledge in Policing and Security', British Journal of Sociology 45(2): 149-175.

Ericson, Richard V. \& Kevin D. Haggerty, 1997. Policing the Risk Society. Oxford: Clarendon.

Ericson, Richard V.; Aaron Doyle \& Dean Barry, 2003. Insurance as Governance. Toronto: Toronto University Press. 
Eriksson, Johan, 1999a. 'Observers or Advocates? On the Political Role of Security Analysts', Cooperation and Conflict 34(3): 311-330.

Eriksson, Johan, 1999b. 'Debating the Politics of Security Studies: Response to Goldmann, Wæver and Williams', Cooperation and Conflict 34(3): 345-352.

Ewald, François, 1986. L'Etat Providence [The Welfare State]. Paris: Editions Grasset.

Ewald, François, 1991. 'Insurance and Risk', in Graham Burchell, Colin Gordon \& Peter Miller, eds, The Foucault Effect: Studies in Governmental Rationality. Hemel Hempstead: Harvester Wheatsheaf (197-210).

Favell, Andrew \& Adrian Geddes, 1990. The Politics of Belonging: Migrants and Minorities in Contemporary Europe. Ashgate: Brookfield.

Fleck, Ludwik, [1935] 1979. Genesis and Development of Scientific Fact. Chicago, IL: University of Chicago Press.

Foucault, Michel, 1994. 'Gouvernementalité' [Governmentality], in Dits et Ecrits [Essential Works of Foucault], vol. 1. Paris: Gallimard (813-828).

Foucault, Michel, 1995. 'La fonction politique de l'intellectuel' [The Political Function of the Intellectual], in Dits et Ecrits [Essential Works of Foucault], vol. 2. Paris: Gallimard (109-114).

Galtung, Johan, 1969. 'Violence, Peace, and Peace Research', Journal of Peace Research 6(3): 167-191.

Galtung, Johan, 2004. Transcend E Transform: An Introduction to Conflict Work. Boulder, CO: Paradigm.

Garland, David, 2001. The Culture of Control: Crime and Social Order in Contemporary Society. Oxford: Oxford University Press.

Gellner, Ernest, 1983. Nations and Nationalism. Oxford: Blackwell.

George, Jim, 1989. 'International Relations and the Search for Thinking Space: Another View of the Third Debate', International Studies Quarterly 33(3): 269-279.

George, Jim, 1994. Discourses of Global Politics: A Critical (Re)Introduction to International Relations. Boulder, CO: Lynne Rienner.

Gianni, Matteo \& Xavier Guillaume, 2004. Unveiling Citizens: Veiling Democracy?, unpublished manuscript, Geneva.

Goldmann, Kjell, 1999. 'Issues, Not Labels, Please!', Cooperation and Conflict 34(3): 331-333.

Guillaume, Xavier, 2002. 'Foreign Policy and the Politics of Alterity: A Dialogical Understanding of International Relations', Millennium: Journal of International Studies 31(1): 1-26.

Guillaume, Xavier, forthcoming. 'Citizenship, Identity, and Securitization: Bringing the Normative Back In'.

Guittet, Emmanuel-Pierre, 2006. 'Military Activities Inside the National Territory: The Case of France', in Didier Bigo \& Anastassia Tsoukala, eds, Illiberal Practices of Liberal Regimes. Paris: L'Harmattan (137-165).

Guzzini, Stefano \& Dietrich Jung, eds, 2004. Contemporary Security Analysis and Copenhagen Peace Research. London: Routledge.

Hacking, Ian, 1990. The Taming of Chance. Cambridge: Cambridge University Press.

Hanon, Jean-Paul, 2000. 'Les coopérations policières aux frontières Schengen germanotchèque et germano-polonaise' [Police Cooperation at the German-Czech and German-Polish Schengen Borders], Les cahiers de la sécurité intérieure 41: 18.

Hansen, Lene, 2006. Security as Practice: Discourse Analysis and the Bosnian War. London \& New York: Routledge.

Hobsbawm, Eric J., 1990. Nations and Nationalism Since 1780: Programme, Myth, Reality. Cambridge: Cambridge University Press.

Huysmans, Jef, 1998a. 'Dire et écrire la sécurité: le dilemme normatif des études de sécurité', Cultures E Conflits 31-32: 177-202; published in English as Jef Huysmans, 2002. 
'Defining Social Constructivism in Security Studies : The Normative Dilemma of Writing Security', Alternatives: Global, Local, Political 27: 41-62.

Huysmans, Jef, 1998b. 'Revisiting Copenhagen: Or, on the Creative Development of a Security Studies Agenda in Europe', European Journal of International Relations 4(4): 479-505.

Huysmans, Jef, 1998c. 'The Question of the Limit: Desecuritization and the Aesthetics of Horror in Political Realism', Millennium: Journal of International Studies 27(3): 569589.

Huysmans, Jef, 2000. 'Migration and the Politics of Security', in Sophie Body-Gendrot \& Marco Martiniello, eds, Minorities in European Cities: The Dynamics of Social Integration and Social Exclusion at the Neighbourhood Level. London: Macmillan (179-189).

Huysmans, Jef, 2002. 'Defining Social Constructivism in Security Studies: The Normative Dilemma of Writing Security', Alternatives 27: 41-62.

Huysmans, Jef, 2004a. 'A Foucaultian View on Spill-Over: Freedom and Security in the EU', Journal of International Relations and Development 7(3): 294-318.

Huysmans, Jef, 2004b. 'Minding Exceptions: Politics of Insecurity and Liberal Democracy', Contemporary Political Theory 3(3): 321-341.

Huysmans, Jef, 2006. The Politics of Insecurity. London: Routledge.

Jeandesboz, Julien, 2005. 'The European Neighbourhood Policy: Analyzing the Securitization of the Union's "External Border"', paper presented at the COST Doctoral Training School 'Critical Approaches to Security Studies', Paris, 16-18 June.

Jutila, Matti, 2006. 'Desecuritizing Minority Rights: Against Determinism', Security Dialogue 37(2): 167-185.

Jutila, Matti; Samu Pehkonen \& Tarja Väyrynen, forthcoming. 'Resuscitating a Discipline: An Agenda for Critical Peace Research'.

Kaldor, Mary, 2001. New and Old Wars. Cambridge: Polity.

Klein, Bradley, 1990. 'How the West Was One: Representational Politics of NATO', International Studies Quarterly 34(2): 311-325.

Krause, Keith, 1998. 'Critical Theory and Security Studies: The Research Programme of "Critical Security Studies"', Cooperation and Conflict 33(3): 298-333.

Krause, Keith \& Michael C. Williams, 1996. 'Broadening the Agenda of Security Studies: Politics and Methods', Mershon International Studies Review 40(2): 229-254.

Krause, Keith \& Michael C. Williams, eds, 1997. Critical Security Studies: Concepts and Cases. London: UCL Press.

Lapid, Josef, 1989. 'The Third Debate: On the Prospects of International Relations in a Post-Positivist Era', International Studies Quarterly 33(3): 235-254.

Lascoumes, Pierre \& Ghislaine Moreau-Capdevielle, 1983. Justice pénale et délinquance d'affaires [Criminal Justice and Trade Delinquency]. Paris: Service d'études pénales et criminologiques.

Lawrence, Philip K., 1996. 'Strategy, Hegemony and Ideology: The Role of Intellectuals', Political Studies 154: 44-59.

Leander, Anna, 2005. 'The Power To Construct International Security: On the Significance of Private Military Companies', Millenium: Journal of International Studies 33(3): 803-826.

Leander, Anna, 2006. 'Privatizing the Politics of Protection: Military Companies and the Definition of Security Concerns', in Jef Huysmans, Andrew Dobson \& Raia Prokhovnik, eds, The Politics of Protection: Sites of Insecurity and Political Agency. London: Routledge (19-33).

Lobo-Guerrero, Luis, 2005. 'Risk, Security and Development, or . . . the Task of "Ennobling" the Savage World', paper presented at the conference 'Security and Development: Recent Trends in Social Science', Nexoe, Denmark, 26 October.

Lobo-Guerrero, Luis, 2006. 'Kidnap and Ransom Insurance: The Micro-Practices of 
Security Through Risk Embracing', paper presented at the 46th Annual Convention of the International Studies Association, San Diego, CA, 23 March.

Luhmann, Niklas, 1993. Risk: A Sociological Theory. New York: Walter de Gruyter.

Lyon, David, 2003. Surveillance After September 11. Cambridge: Polity.

McCormack, Tara, forthcoming. 'Human Security and Sovereignty', in Chris Bickerton, Philip Cunliffe \& Alex Gourevitch, eds, Politics Without Sovereignty: A Critique of Contemporary International Relations. London: UCL Press.

McSweeney, Bill, 1996. 'Identity and Security: Buzan and the Copenhagen School', Review of International Studies 22(1): 81-93.

McSweeney, Bill, 1998. 'Durkheim and the Copenhagen School: A Response to Buzan and Wæver', Review of International Studies 24(1): 137-140.

McSweeney, Bill, 1999. Security, Identity, and Interests: A Sociology of International Relations. Cambridge: Cambridge University Press.

Malin, Martin \& Robert Latham, 2001. 'The Public Relevance of International Security Research in an Era of Globalism', International Studies Perspectives 2(2): 221-230.

Muller, Benjamin J., 2004. '(Dis)qualified bodies: Securitization, Citizenship and Identity Management', Citizenship Studies 8(4): 279-294.

Müller, Jan-Werner, ed., 2002. Memory and Power in Post-War Europe: Studies in the Presence of the Past. Cambridge: Cambridge University Press.

Neumann, Iver B., 1995. Russia and the Idea of Europe: A Study in Identity and International Relations. London \& New York: Routledge.

Neumann, Iver B., 1999. Uses of the Other: 'The East' in European Identity Formation. Minneapolis, MN: University of Minnesota Press.

Nyers, Peter, 2006. 'Taking Rights, Mediating Wrongs: Disagreements over the Political Agency of Non-Status Refugees', in Jef Huysmans, Andrew Dobson \& Raia Prokhovnik, eds, The Politics of Protection: Sites of Insecurity and Political Agency. London: Routledge (48-67).

O'Malley, Pat, 1998. Crime and the Risk Society. Aldershot: Dartmouth.

O'Malley, Pat, 2000. 'Uncertain Subjects: Risk, Liberalism and Contract', Economy and Society 29: 460-484.

O'Malley, Pat, 2004. Risk, Uncertainty and Government. London: Glasshouse.

Olsson, Christian, 2003. 'Vrais procès et faux débats: perspectives critiques sur les argumentaires de légitimation des entreprises de coercition para-privées' [True Trials and False Debates: Critical Perspectives on the Legitimizing Discourses of Para-Private Military Companies], Cultures \& Conflits 52: 11-48.

Olsson, Christian, 2006a. 'Military Interventions and the Concept of the Political: Bringing the Political Back into the Interactions Between External Forces and Local Societies', in Didier Bigo \& Anastassia Tsoukala, eds, Illiberal Practices of Liberal Regimes. Paris: L'Harmattan (165-204).

Olsson, Christian, 2006b forthcoming. 'The Politics of the Apolitical, PMCs, Humanitarians and the Quest for (Anti-)politics in Post-Intervention Environments'.

Patomäki, Heikki, 2001. 'The Challenge of Critical Theories: Peace Research at the Start of the New Century', Journal of Peace Research (38)6: 723-737.

Petersen, Karen, 2006. 'Terrorism: When Risk Meets Security', paper presented at the 46th Annual Convention of the International Studies Association, San Diego, CA, 23 March.

Portes, Alejandro, 1998. 'Globalization from Below: The Rise of Transnational Communities', Transnational Communities Working Paper WPTC-98-01; available at http://www.transcomm.ox.ac.uk/working_papers.htm.

Portes, Alejandro, 2001. 'Introduction: The Debates and Significance of Immigrant Transnationalism', Global Networks 3(1): 181-193. 
Posen, Barry, 1993. 'The Security Dilemma and Ethnic Conflict', in Michael E. Brown, ed., Ethnic Conflict and International Security. Princeton, NJ: Princeton University Press (103-124).

Power, Michael, 2004. The Risk Management of Everything: Rethinking the Politics of Uncertainty. London: Demos.

Prozorov, Sergei, 2005. 'X/Xs: Toward a General Theory of the Exception', Alternatives 30(1): 81-112.

Ragazzi, Francesco, 2005. "'Diasporitisation?": Diaspora Mobilisation as Long-Distance Securitization', paper presented at the 45th Annual Convention of the International Studies Association, Honolulu, HI, 27 February.

Rasmussen, Mikkel V., 2002. 'A Parallel Globalisation of Terror: 9-11, Security and Globalisation', Cooperation and Conflict 37(3): 323-349.

Rasmussen, Mikkel V., 2004. 'It Sounds Like a Riddle: Security Studies, the War on Terror and Risk', Millennium: Journal of International Studies 33(2): 381-395.

Roe, Paul, 2004. 'Securitization and Minority Rights: Conditions of Desecuritization', Security Dialogue 35(3): 279-294.

Rytövuori-Apunen, Helena, 1990. Peace Research in Scandinavia, 1959-1986. Avebury: Aldershot.

Said, Edward, 1979. Orientalism. New York: Vintage.

Schmitt, Carl, [1922] 1985. Political Theology: Four Chapters on the Concept of Sovereignty, trans. George Schwab. Cambridge, MA: MIT Press.

Schmitt, Carl, [1932] 1996. The Concept of the Political, trans. George Schwab. Chicago, IL: University of Chicago Press.

Schmitt, Carl, [1950] 2003. The Nomos of the Earth in the International Law of the Jus Publicum Europaeum, trans. G. L. Ulmen. New York: Telos.

Schmitt, Carl, [1932] 2004. Legality and Legitimacy, trans. Jeffrey Seitzer. Durham, NC: Duke University Press.

Sheehan, Michael, 2005. International Security: An Analytical Survey. Boulder, CO: Lynne Rienner.

Stritzel, Holger, 2005. 'Securitisation Theory and the Politics of Threat Images: A Critical Appraisal', paper presented at the COST Doctoral Training School 'Critical Approaches to Security in Europe', Paris, 16 June.

Stritzel, Holger, 2006. 'Towards a Theory of Securitisation: Copenhagen and Beyond', paper presented at the 46th Annual Convention of the International Studies Association, San Diego, CA, 22 March.

Thompson, Janice E., 1994. Mercenaries, Pirates and Sovereigns: State-Building and ExtraTerritorial Violence in Early Modern Europe. Princeton, NJ: Princeton University Press.

Tsoukala, Anastassia, 2004. 'Les nouvelles politiques de contrôle du hooliganisme en Europe : de la fusion sécuritaire au multipositionnement de la menace' [The New Policies of Controlling Hooliganism in Europe: From the Fusion of Security to the Multi-Positioning of Threats], Cultures \& Conflits 51: 83-96.

United Nations Development Programme, 1994. Human Development Report. New York: Oxford University Press.

Van Munster, Rens, 2004. 'The War on Terrorism: When the Exception Becomes the Rule', International Journal for the Semiotics of Law 17(2): 141-153.

Väyrynen, Tarja, 2005. 'A Shared Understanding: Gadamer and International Conflict Resolution', Journal of Peace Research 42(3): 347-355.

Wæver, Ole, 1989a. 'Security, the Speech Act: Analyzing the Politics of a Word (and the Transformation of a Continent)', unpublished manuscript.

Wæver, Ole, 1989b. 'Moment of the Move: Politico-Linguistic Strategies of Western Peace Movements', paper presented at the 12th annual scientific meeting of the International 
Society of Political Psychology, Tel Aviv, 18-22 June; reprinted in Ole Wæver, 1997, Concepts of Security. Copenhagen: University of Copenhagen (183-210).

Wæver, Ole, 1993. 'Societal Security: The Concept', in Ole Wæver, Barry Buzan, Morten Kelstrup \& Pierre Lemaitre, Identity, Migration and the New Security Agenda in Europe. London: Pinter (17-40).

Wæver, Ole, 1995. 'Securitization and Desecuritization', in Ronnie D. Lipschutz, ed., On Security. New York: Columbia University Press (46-86).

Wæver, Ole, 1998. 'Insécurité, identité, une dialectique sans fin' [Insecurity, Identity, an Endless Dialectic], in Anne-Marie Le Gloannec, ed., Entre Union et Nation. L'Etat en Europe [Between Union and Nation, the State in Europe]. Paris: Presses de Sciences Po (91-138).

Wæver, Ole, 1999. 'Securitizing Sectors? Reply to Eriksson', Cooperation and Conflict 34(3): 334-340.

Wæver, Ole, 2000. 'The EU as a Security Actor: Reflections from a Pessimistic Constructivist on Post Sovereign Security Orders', in Morten Kelstrup \& Michael C. Williams, eds, International Relations Theory and the Politics of European Integration. London: Routledge (250-294).

Wæver, Ole, 2003. 'Securitisation: Taking Stock of a Research Programme in Security Studies', unpublished manuscript.

Wæver, Ole, 2004a. 'Aberystwyth, Paris, Copenhagen: New "Schools" in Security Theory and Their Origins Between Core and Periphery', paper presented at the 45th Annual Convention of the International Studies Association, Montreal, Canada, 17-20 March.

Wæver, Ole, 2004b. 'Peace and Security: Two Concepts and Their Relationship', in Stefano Guzzini \& Dietrich Jung, eds, Contemporary Security Analysis and Copenhagen Peace Research. London: Routledge (53-65).

Walker, Rob B. J., 1980. Political Theory and the Transformation of World Politics, Occasional Paper No. 8. Princeton, NJ: Center for International Studies, World Order Studies Program.

Walker, Rob B. J., 1983. 'Contemporary Militarism and the Discourse of Dissent', Alternatives 9(3): 345-364; reprinted in Rob Walker, ed., 1984, Culture, Ideology, World Order. Boulder, CO \& London: Westview (302-322).

Walker, Rob B. J., 1987. 'Realism, Change and International Political Theory', International Studies Quarterly 31(1): 65-86.

Walker, Rob B. J., 1988. The Concept of Security and International Relations Theory, Working Paper No.3. La Jolla, CA: Institute on Global Conflict and Cooperation, University of California, San Diego.

Walker, Rob B. J., 1993. Inside/Outside: International Relations as Political Theory. Cambridge: Cambridge University Press.

Walker, Rob B. J., forthcoming. After the Globe/Before the World.

Wallensteen, Peter, 1988. 'The Origins of Peace Research', in Peter Wallensteen, ed., Peace Research: Achievements and Challenges. London: Westview (7-29).

Wendt, Alexander, 1992. 'Anarchy Is What States Make of It', International Organization 46(2): 391-425.

Wendt, Alexander, 1999. Social Theory of International Politics. Cambridge: Cambridge University Press.

Williams, Michael C., 1998. 'Modernity, Identity and Security: A Comment on the "Copenhagen controversy"', Review of International Studies 23(3): 435-440.

Williams, Michael C., 1999. 'The Practices of Security: Critical Contributions - Reply to Eriksson', Cooperation and Conflict 34(3): 341-344.

Williams, Michael C., 2003. 'Words, Images, Enemies: Securitization and International Politics', International Studies Quarterly 47(4): 511-532. 
Wyn Jones, Richard, 1999. Security, Strategy, and Critical Theory. London: Lynne Rienner. Wyn Jones, Richard, 2001. Critical Theory and World Politics. Boulder, CO: Lynne Rienner. Wyn Jones, Richard, 2005. 'On Emancipation: Necessity, Capacity and Concrete Utopias', in Ken Booth, ed., Critical Security Studies and World Politics. London: Lynne Rienner (215-235).

Žižek, Slavoj, 2004. Iraq: The Borrowed Kettle. London: Verso. 